\title{
Exploring the urban water-energy-food nexus under environmental hazards within the Nile
}

DOI:

10.1007/s00477-019-01706-x

\section{Document Version}

Accepted author manuscript

Link to publication record in Manchester Research Explorer

\section{Citation for published version (APA):}

Elagib, N. A., Gayoum Saad, S. A., Basheer, M., Rahma, A. E., \& Gore, E. D. L. (2019). Exploring the urban waterenergy-food nexus under environmental hazards within the Nile. Stochastic Environmental Research and Risk Assessment. https://doi.org/10.1007/s00477-019-01706-x

\section{Published in:}

Stochastic Environmental Research and Risk Assessment

\section{Citing this paper}

Please note that where the full-text provided on Manchester Research Explorer is the Author Accepted Manuscript or Proof version this may differ from the final Published version. If citing, it is advised that you check and use the publisher's definitive version.

\section{General rights}

Copyright and moral rights for the publications made accessible in the Research Explorer are retained by the authors and/or other copyright owners and it is a condition of accessing publications that users recognise and abide by the legal requirements associated with these rights.

\section{Takedown policy}

If you believe that this document breaches copyright please refer to the University of Manchester's Takedown Procedures [http://man.ac.uk/04Y6Bo] or contact uml.scholarlycommunications@manchester.ac.uk providing relevant details, so we can investigate your claim.

\section{OPEN ACCESS}


${ }^{2}$ Al Rawabi Dairy Company, P.O. Box 50368, Dubai, United Arab Emirates Science and Technology, Khartoum North, Sudan ${ }^{4}$ College of Water Conservancy and Civil Engineering, Shandong Agricultural University, Taian, 


\section{Abstract}

The integrative approach of water, energy, and food nexus (WEF nexus) is now widely accepted to offer better planning, development, and operation of these resources. This study presents a first attempt towards understanding the WEF nexus of urban environments in the Nile River Basin under conditions of hydrological droughts and fluvial floods. A case study was conducted for the capital of Sudan, Khartoum, at the confluence of the White Nile and the Blue Nile for illustration. The results were based on analyses of river flow and water turbidity data, field observations, a printed questionnaire and an interview of farmers practicing irrigated agriculture, and hydropower modelling. The study analyzes indicators for the association of river water resources environment (intra-annual regime, quantity, and quality), the status of urban irrigated agriculture, water treatment for domestic use, and hydropower generation under hydrological extremes, i.e. droughts and fluvial floods. It additionally examines the consequent interactions between the impacts on three sectors. The present study shows how floods and droughts impose impacts on the seasonal river water quality and quantity and, in turn, on the water treatment for domestic use, irrigated agriculture, and hydro-energy supply in an urban environment. The results demonstrate how the two hydrological phenomena determine the state of hydropower generation from dams, i.e. high energy production during floods and vice versa during droughts. Hydropower dams, in turn, could induce cons in the form of low fertile soils in the downstream due to retaining sediment. Finally, present and potential options to minimize the above risks are discussed. This study is hoped to offer a good support for integrated decision making on increased resource efficiency over the urban environment within the Nile Basin. 
41 Keywords: Hydrological drought; Fluvial flood; Water turbidity; Urban irrigated agriculture; Water treatment; Hydropower

\section{Introduction}

Weather- and water-related disasters occurring as a result of random processes, such as droughts and floods, have grown rapidly and they affect human beings, bringing suffering, death, and immense material losses (Kundzewicz et al. 2003, 2007). On one hand, floods affect human activities and economy through many sectors including water supply, health, agriculture, transportation, navigation systems, and fisheries (Posthumus et al. 2009, Du et al. 2010, Merz et al. 2010; Abbas and Routray 2013, Dewan 2015, Sultana and Thompson 2018). Despite the debate on the cause of extreme river floods, these events have underscored several lessons as stated by Savenije (1995). These lessons state that: (1) previous knowledge about our rivers are out of date since considerable changes have taken place in these rivers, (2) our understanding of the physical processes of rivers is insufficient, and (3) there is a societal lack of awareness of the hydrological systems in which we are living. On the other hand, large urban centres, with their high populations, are water-sensitive areas since they require large amounts of fresh water for consumption and sanitation (Leathers et al. 2000, Boadi et al. 2005). Bordi et al. (2009) stated that “the degree of a region's vulnerability depends on many environmental and social factors as well as on the ability to anticipate, cope with, and recover from drought". This statement further means that drought severity is dependent on water shortage as well as on water use (Rao and Voeller 1997). In addition to water supply, soil erosion, crop production, and hydroelectric power generation are also severely affected by the events of drought (Landsberg 1982). Water utilities are prioritized by managing water-supply droughts (Walker and Smithers 1995), and the measures used to assess drought in terms of impacts on water utilities are categorized as water resources indicators 
(Mawdsley et al. 1994). Both droughts and floods can have serious impacts on water quality (Hrdinka et al. 2012). Therefore, freshwater planning and management merits advanced understanding and assessment of historical drought and flood hazards and their impacts at both regional and local levels (Leathers et al. 2000, Merz et al. 2010, Mishra and Singh 2010) on the different resources, such as water, food, and energy. Traditionally, each of these resources and their utilities are planned, developed and managed in isolation of the others; however, "balancing different resource user goals and interests - while maintaining the integrity of ecosystems" (FAO 2014) is nowadays becoming a concern mainly tackled by the water-energy-food nexus (WEF nexus) concept. To improve the current status of developing the integrative concepts of the nexus, Al-Saidi and Elagib (2017) recommend exploring driving forces and interactions of the resources on different scales and across different sectors. The WEF nexus becomes even more complicated under stochastic phenomena, such as droughts and floods. Like many African countries, the pursuit of human advancement and urbanization in the countries within the Nile River Basin has created an imbalance between socio-economic development and environmental welfare, especially in large cities. The uneven spatial development of services across several countries resulted in a rapid growth in urban populations due to rural-urban migration because of the deteriorating rural livelihoods (Boadi et al. 2005). In this regard, the capital of Sudan, Khartoum State, has become progressively urbanized in many aspects, such as outstanding population agglomeration accompanied by expansion of construction and other human activities (Elagib 2011). What makes Khartoum State vulnerable to fluvial flooding is that it is incised by the flow of two rivers, i.e. the Blue Nile and the White Nile, which confluence in the middle of the state (Fig. 1). For several decades, Khartoum State has been pinpointed as a region with high inter-relationship between socioeconomic development and urbanization (El Nour and Balla 1989). Urban agriculture in Khartoum State is a common practice along, and in the periodically flooded soils adjacent to, the River Nile banks 
87 (Abdalla et al. 2012). Expansion of land for urban agriculture has led to substantial increases in water use during the last five decades (Schumacher et al. 2009). In comparison to other urban centres in Sudan, faster interactions between intensified desert conditions and rapid urbanization were clearly exemplified by Babiker (1982) in the case of Khartoum, not only because Khartoum is the largest urban centre with the highest rate of population growth, but also because of its location in a more ecologically vulnerable region. It is generally accepted that supply of water resources is affected by different climatic, hydrological and anthropogenic factors. These factors operate differently at various temporal and spatial scales. Although Khartoum is rich of water resources, and despite the substantial progress in the improvement of the water supply and distribution system, these systems are still largely inadequate to meet the demands; hence, water supply and accessibility still induce considerable challenges to the governmental water supply system of the state (Abdalla et al. 2010).

In the last couple of years, considerable efforts have been made to understand the inseparable links between the water, energy and food resources of the Nile using the WEF nexus approach. For example, Al-Saidi et al. (2017) used this approach to highlight the issues for transboundary cooperation within the Eastern Nile Basin. Further, Al-Saidi and Hefny (2018) utilized the interlinked water, energy and land resources approach to conceptualize the process of transboundary cooperation and address the underlying water diplomacy challenges within the Eastern Nile Basin. Another study (Basheer et al. 2018) developed a daily hydro-economic model of the Blue Nile Basin to quantify the long-term direct economic gain from implementing infrastructure development plans for Sudan, Ethiopia and the whole basin. Basheer and Elagib (2018) introduced the concept of water-energy productivity to explore the sensitivity of water-energy interdependencies to dam operation by modeling the White Nile, including Jebel Aulia Dam, in Sudan. Stamou and Rutschmann (2018) assessed the water resources in the Upper Blue Nile Basin by optimizing the interacting WEF sectors to enable a co-benefit scenario. 
Al-Saidi and Elagib (2017) concluded that the WEF nexus should be analysed on a case-by-case

111 basis without generalization or pushing an ultimate model. Despite the aforementioned research on 112 improving the understanding of the WEF nexus in the context of the Nile, the urban facet of the nexus 113 does not seem to feature in the ongoing discourse. Roidt and Avellán (2019) defines the integrated 114 management approach of the WEF nexus, i.e. water supply, food and energy sectors, in terms of concept 115 of integration category and an aspect as follows. The former describes the connection between two 116 aspects whereas the latter is defined as a particular part or feature of the approach and includes the 117 systems, i.e. water, energy and food. Thus, when adopting the nexus, they consider water to generate 118 energy, energy to supply water, water to grow food, food to produce energy, etc. as representing the 119 categories to be integrated, either partly or all. Zhang et al. (2018) identify the research priorities for 120 the interdependency of the WEF systems and suggest research method for their implementation for 121 each system scale. They emphasize the need for representing more detail of the inner social and physical mechanisms of the nexus system on the small research scale of a city. Therefore, the objectives of this study are: (1) to analyze possible urban WEF nexus indicators under hydrological drought and riverine flood, (2) to examine how extreme such hazards are in terms of seasonal and cumulative environmental consequences assessed by the nexus linkages within three activities ,namely urban farming, water treatment for domestic use and hydropower generation, and (3)

127 to discuss and offer recommendations to minimize the associated risks and secure WEF resources 128 within the three sectors, i.e. domestic water supply, urban agriculture and hydropower energy, if there 129 would be a return of hydrological hazards. 


\section{Study area}

133 Figure 1 shows the location of the study area. Khartoum State, the capital of Sudan, has an area of

134 around $21,000 \mathrm{~km}^{2}$ which accounts for approximately $0.01 \%$ of the total area of the country.

135 Conversely, Khartoum is characterised by a rapid population growth with nearly $20 \%$ of the population

136 of Sudan residing within the state. The population of Khartoum is between 6 to 7 million as estimated

137 by the Sudan Population (2018). Khartoum has a unique location due to the confluence of the two main

138 tributaries of the Nile River, i.e. the Blue and the While Niles, within the state to form the Main Nile.

139 The three river courses divide the state into three parts: Khartoum City which is located between the

140 Blue Nile and the White Nile; Khartoum North (Bahri) which is located between the Blue Nile and the

141 Main Nile; Omdurman which is located west of the White Nile and the Main Nile. Whereas high

142 seasonality characterises the flow of the Blue Nile with nearly $80 \%$ of the annual flow occurring from

143 July to October (Conway 1997), relatively regular flow is a feature of the White Nile due to the presence

144 of the Sudd swamps in its upstream (Sutcliffe and Parks 1999, Basheer and Elagib 2018). The Blue

145 Nile and the White Nile contribute around 57 and 30\%, respectively, of the flow of the Nile River

146 measured near the Sudanese-Egyptian border (NBI 2012). Khartoum State is featured by fast expansion

147 of settlement, industrial, and business areas and extreme hydro-meteorological phenomena, such as

148 urban heat island, intensifying aridity, and pluvial and fluvial floods (Sutcliffe et al. 1989, Walsh et al.

149 1994, Davies and Walsh 1997, Elagib 2009, 2011, Elagib and Elhag 2011, Mahmoud et al. 2014,

150 Mahmood et al. 2017).

151 Khartoum is supplied with electricity through the national Sudanese grid which combines

152 energy generation from several hydro- and thermal-power sources around the country. Two of the

153 hydropower sources that feed the Sudanese grid and supply Khartoum State are Roseires and Jebel

154 Aulia dams. The construction of the first phase of Roseires Dam was completed in 1966 to provide 
155 Gezira Scheme with irrigation water and to generate hydropower through seven 40-MW turbines 156 (MoIHES 1977). The second phase of the dam was completed in 2013 to add $10 \mathrm{~m}$ to its original height 157 (DIU 2016). Despite that the construction of Jebel Aulia Dam was completed since 1937 (Sobeir 1983), 158 it was not until 2002-2005 that hydropower unites were added to the dam with a total capacity of 30.4 159 MW (ANDRITZ Hydro 2013). Lastly, several Water Treatment Plants (WTPs), along with 160 groundwater wells with varying depths and productivity, supply drinking water to Khartoum State. 161 Those WTPs have been installed along the Nile during the period 1924 to 2010 (Fig. 1), and the 162 evolution of their number indicate an increasing water demand within the state.

163

164

165

166

\section{Data and methods}

\subsection{Data used}

The present work integrates several kinds of data to understand the urban WEF nexus under the hydrological risk in the Nile basin as follows:

- Hydrological observations: Monthly river flow at Khartoum gaging station on the Blue Nile from the Ministry of Water Resources, Irrigation, and Electricity of Sudan for the period 19652017.

- Daily water turbidity measurements for the Blue Nile near Bahri Water Treatment Plant (WTP) for the period 2007-2010. These data were acquired from the Sudanese Central Laboratory and Bahri WTP. Even though the turbidity time series had gaps ranging from one day to several days, the gaps represent $<10 \%$ of the dataset. The Gaps were filled by using a cubic spline calculation (Lewis and Eads 2009) such that (1) daily mean turbidity of the estimated data matched the daily mean observed turbidity, (2) estimated data were calculated at the same time intervals and are continuous with respect to observed data and to first and second derivatives, 
and (3) the turbidity data were correlated using observed data from a nearby point with a concurrent record.

- Structured questionnaire consisting of a series of printed multiple choice question that took place during 2017 with 50 farmers who practice irrigated agriculture along the Nile bank in four locations, namely Elgezira Slang, Shambat, Elfaki Hashim and Elgeraif, in Khartoum State (Fig. 1). The details of the questionnaires as regards the survey administration, the

- Interviews carried out during a field visit in March 2015 with farmers who cultivate on the river banks to express their views on the impacts of sedimentation and river erosion.

- Several kinds of data were used to estimate the daily energy production for Roseires and Jebel Aulia dams by river basin modelling. These data included river flow, rainfall, water demands of large-scale irrigation, and outlets capacities, operating policies, turbines specifications, and reservoirs geometry of dams. These data were obtained from several sources including the Ministry of Water Resources, Irrigation, and Electricity of Sudan, the Sudan Meteorological Authority, the Eastern Nile Technical Regional Office of the Nile Basin Initiative, and Wheeler et al. (2016). Moreover, the African Rainfall Climatology Version 2 (ARC2; Novella and Thiaw (2013)) satellite data were used, after evaluation, to substitute the sparse ground rainfall data in the study region. The reader is referred to Basheer et al. (2018) for more information about the procedure that has been followed to evaluate ARC2. Shuttle Radar Topography Mission (SRTM; Jarvis et al. (2008)) topographic data were used to delineate sub-basins and the Moderate Resolution Imaging Spectroradiometer Global Evapotranspiration Project (MOD16; Mu et al. (2011) data were used to estimate average actual evapotranspiration from 

data.

\subsection{Nexus concept of the present study}

With the nexus background reviewed in the introduction, the understanding of the impact of hydroenvironmental hazards on the urban WEF nexus within the Nile is built herein on the conceptual framework shown in Fig. 2. It is not claimed that this framework is a comprehensive one, but it is rather deemed a first-step towards this understanding. In this approach, climate variations are considered as a trigger of the hydrological hazards, i.e. drought and floods. These hazards reflect into indicators of nexus systems, i.e. water, energy and food, and are represented respectively by the status of water quality and quantity (water environment), hydropower generation from dams, and urban agricultural activities. These indicators translate into understanding of the interlinked impacts between the corresponding water, energy, and food securities. As indicated by the up-down arrows in Fig. 2, the interlinkages were discussed in three dimensions. In the first dimension, the WEF nexus in urban agriculture was investigated in view of, for example, the influence of floods and droughts on the pumping energy (water-energy nexus), which in turn necessary for facilitating crop irrigation of (WEF nexus), and on the availability of land for cropping. The influence of energy availability on transporting food crops (energy-food nexus) within the capital was also discussed. Secondly, the implications of several environmental problems, such as algal growth and siltation, for the water-energy nexus in the process of river water treatment for domestic use were demonstrated under drought and flood events. The third dimension demonstrates the influence of hydrological droughts and floods on the waterenergy nexus in hydropower production from two dams which supply energy to Khartoum. Finally, the established understanding of the impacts on the WEF nexus would lead to interventions to adapt to 
hydro-environmental hazards within urban environments through measures to secure water, energy and food. To achieve the above understanding, several methods and data have been employed as described in the following part of Section 3.

\subsection{Analysis of flood and drought events using streamflow drought index}

228 The streamflow drought index (SDI) is widely used to characterize hydrological droughts (Shukla and 229 Wood 2008; Nalbantis and Tsakiris 2009) in terms of wet and dry years relative to the average 230 condition. In this study, a temporal analysis of monthly and annual river flow data was performed to 231 develop the SDI for 1965 to 2017 as follows. The distribution of flow data was checked for normality 232 by calculating the skewness coefficient (Sk). If the Sk was far from zero, the data were normalized by 233 attempting several transformation functions, such as logarithmic, square root, etc until near-zero Sk 234 was reached. The mean, the standard deviation, and the deviation from the mean of the transformed 235 (normal) flow data set were then calculated. Those deviations (anomalies) were finally divided by the standard deviation to obtain the SDIs. Positive anomalies refer to wet events whereas negative anomalies indicate dry events with respect to the average river flow. To identify the monthly contribution to annual drought/flood incidences, the relationship between the annual and monthly SDIs

239 for 1965 to 2017 was examined using the non-parametric, one-tailed Kendal tau correlation test (Kanji 240 2006). Then, recently reported river flood and drought years, i.e. respectively 2006 and 2010, were 241 selected to examine the urban WEF nexus under these two conditions. 


\subsection{Hydropower modeling}

245 Daily energy production data for Roseires and Jebel Aulia dams for the period 2006-2010 were 246 generated utilizing river basin models of the Blue Nile and the White Nile. The two models have been 247 developed for the two rivers respectively by Basheer et al. (2018) and Basheer and Elagib (2018). The 248 Blue Nile and the White Nile models have daily and monthly time steps, respectively. For this study, 249 the monthly White Nile model was transformed into a daily model to produce daily energy generation 250 data for Jebel Aulia Dam. This transformation was performed by replacing the monthly river flow and 251 water abstractions with daily data and adjusting the system operating rules. The two models were 252 created using a river and reservoir simulation tool, i.e. RiverWare (Zagona et al. 2001), and a rainfall253 runoff modelling tool, i.e. The Hydrologic Engineering Center-Hydrologic Modelling System (HEC254 HMS; HEC (2000)). RiverWare is an object-oriented water allocation modelling tool that supports prioritized rule-based simulation (Zagona et al. 2001). RiverWare has a policy language that provides flexibility in modeling dam operating rules (Wheeler et al. 2018). HEC-HMS is a tool that simulates rainfall-runoff of dendritic watersheds using mostly lumped conceptual and empirical methods. In developing the Blue Nile and the White Nile models, constant travel times and loss percentages were used to simulate lag time and transmission losses, respectively. Moreover, the models used a soil deficit accounting method to simulate soil infiltration and percolation, a constant capacity to simulate canopy interception, and Snyder unit hydrograph to simulate water transformation in sub-basins.

\subsection{Analysis of flow, turbidity, and hydro-energy}

264 In this analysis, the annual cycles of both the river flow and turbidity were compared for index wet and 265 dry years (2006-2010) to study the influence of floods and droughts, respectively, on the occurrence of 266 peaks of the two variables, the time lag between those peaks, and the seasonal behaviour of the river 
flow and turbidity. Furthermore, the relationship between the two elements was investigated for different seasons. The results of these analyses were used in the discussion of the influence of hydroenvironmental hazards on the WEF nexus.

Regarding the hydro-energy, the probability of exceedance of the daily energy generation was calculated and compared to illustrate the influence of floods and droughts on the water-energy nexus as indicated by the firm energy generation, the probability of energy generation at the installed capacity, and the total annual energy generation. Moreover, the annual hydro-energy generation was studied to understand the interplay of system operating policies and energy generation in the events of floods and droughts.

\subsection{Questionnaire about adaptation of urban agriculture to hydro-environmental hazards}

278 A questionnaire was randomly distributed to a total of50 famers in five locations as follows: 10 farmers in Elgezira Slang, 10 farmers in Shambat, 14 farmers in Elfaki Hashim, and 16 farmers in Elgeraif. Figure 1 shows the five locations and Table 1 presents the nature of the questionnaire questions. The questionnaire was translated from English into Arabic to facilitate communication with the respondents. In each case, the farmer requested to be informed of the content of the questionnaire before consenting and responding to it. Filling each questionnaire form took 5 to 10 minutes, and was under close supervision and full participation of the researcher. Selection of the farmers was aimed to achieve certain criteria, including a wide-range of household characteristics, crop type, and cultivars. All farmers were males (a characteristic of urban agriculture) who were the fathers and heads of their 287 families and were aging from 30 to 70 years old, working in farming for 8 to 55 years. Around 94\% of 288 the interviewed farmers had primary, intermediate, and secondary level of education and all of them 289 had a family size of 3 to 12 persons. Three main kinds of occupation were identified for the farmers: 
farming was identified for $72 \%$ of them while farming and pastoralism or farming and trading was recognized for $28 \%$ of the households. Farming represents the main source of income for all except one of the households. All the farmers produce onion, potato or other kinds of vegetables and sell their products solely in the local market.

The purpose of the questionnaire was to explore how farmers perceive the impacts of climate

295 variations-induced consequences, i.e. hydrological drought and/or flood, on urban agriculture and how they respond to these risks, which lead to crop loss and decline of crop productivity. Therefore, the topics investigated among the farmers included their perceptions of the reasons behind the decline of production, farmers' adaptation options, and barriers to farmers' adaptive capacities (Table 1). In formulating the questionnaire, a recent experience in Sudan was taken into account (Elagib et al. 2017). The respondents were allowed to select more than one answer.

\section{Results and discussion}

\subsection{Flood and drought events}

Fig. 3 shows the temporal SDI of the monthly and annual time scales for the Blue Nile at Khartoum gaging station. April and September were selected to represent a summer-dry and a summer-wet month (Conway 1997), respectively. Since July-September is the main rainfall season across the Blue Nile, rainfall in this period contributes the major volume of flow as will be shown by the hydrograph in the next section. Therefore, September SDI time series correlates significantly (tau $=0.644 ; p=0.001$ ) with the annual SDI unlike the case of April SDI time series. During the 53-year period, the 1980s represented the driest decade, which is characterized by successive dry years. This drought period (referred to as the Sahel drought) is well documented in the literature (Sutcliffe and Parks 1999). The temporal analysis of SDIs reveals 27, 28 and 24 negative anomalies but 26, 25 and 29 positive 
anomalies, respectively for April, September, and annual time series. The above- and below-average

314 flows within the present up-to-date data also confirm the characteristic fluctuations exhibited by the

315 Nile flows during earlier decades (Conway and Hulme 1993). Another up-to-date feature is the 316 increased and successive number of years of positives anomalies during the $20^{\text {th }}$ century. These 317 observations could be a result of extensive land use and land cover changes (Tekleab et al. 2013; 318 Woldesenbet et al. 2017) and significant increase in heavy and extreme rainfall events (Degefu and 319 Bewket 2014; Worku et al. 2018) in the Upper Blue Nile in Ethiopia during the recent years. Increasing 320 trends of maximum and minimum flows at an upstream gaging station of the Blue Nile in Sudan was 321 reported by Taye et al. (2015) up to the year 2009. The year 2007 was the wettest during the period of 322 recovery from the Sahel drought (Figs. $3 b$ and 3c). This observation corresponds to reports of 323 exceptional rains and floodings in the Sahel and sub-Saharan Africa (Paeth et al. 2011; Samimi et al. 324 2012). Of particular interest for the present study are the years 2006 and 2010 for which the SDIs 325 indicate a fluvial flood event in September and a hydrological drought occurrence in April, respectively, 326 the impacts of which will be elaborated in the following sections. The SDI show a value of 1.73 for 327 September 2006 but a value of -1.78 for April 2010. It is interesting to note as well that the overall 328 annual flow during the year 2009 was also low (Fig. 3c), thus aggravating the drought situation of the 329 dry early part of the year 2010. It is worthwhile noticing, on the other hand, that multi-year drought 330 events have also occurred during the $20^{\text {th }}$ century (Fig. 3).

\subsection{Water environment during flood and drought}

333 The water environment in the present study refers to the quantity and quality of the Nile water resource.

334 The annual cycle of both the flow and turbidity levels is exhibited in Fig. 4 for five and four years, 335 respectively. To discuss the pattern of these cycles, one needs to put it in context of the drought and 
flood events indicated by the SDIs in Fig. 3. On the annual scale, four years are characterized by aboveaverage flows, namely 2006, 2007, 2008 and 2010, whereas 2009 indicates below-average flow. The peak flow always occurs during late August to early September (Table 2); however, two secondary peaks occur before and after the wet season (July to September), as seen in Fig. 3, which resemble the climatological rainy season in East Africa (Seregina et al. 2018). The one preceding the wettest part of the year is recorded during June/July whereas the one following the wet season is registered in October/November. As reported in Table 2 , the intra-annual variability was lowest $(\sim 130 \%)$ during the wettest year (2007) but highest (>150\%) during the driest year (2009) or the year that encountered too dry summer season (April 2010). This behaviour is even more pronounced for the wet season flow data when the intra-annual coefficient of variation dropped to $32.7 \%$ but escalated to $75.7 \%$ in 2007 and 2009, respectively.

As for the turbidity annual cycle (Fig. 4), notably high turbidity levels occur during the wet season (July-September) with always a sharp peak during July, i.e. much earlier to the flow peak (Table 2). In 2010, when the preceding season to the wettest part of the year was too dry, the time lag between the turbidity and flow peaks was the shortest, i.e. only 12 days, compared to the longest lag (as long as 66 days) evidenced in the wettest year 2007. The delay of flow peaks behind turbidity peaks could be a result of sediment transport regime in this area; however, this causation needs more investigation of sediment criteria. A study from the United States of America showed coincidence of flow and turbidity peaks in snow melting seasons, and that the change in level of suspended solids in rivers (and hence turbidity) with changing water depths and velocities is rapid and unpredictable (Susfalk et al. 2008). The same study also emphasized that adequate characterization of the inherent temporal variability of 357 the process will require a large number of water quality samples. In the present study, the highest 358 turbidity level was recorded during the year with the lowest flow (2009). Similarly, the highest intra- 
annual coefficient of variability of turbidity $(84.1 \%)$ was found to characterize the wet season of this driest year (see Table 2).

Figure 5 shows a well-established linear relationship between the Blue Nile river flow at Khartoum station and turbidity level on a log-log scale, with a variation among the years and the seasons of the year. Such seasonal flow-versus-turbidity relationships are quite informative. It can be clearly noticed that the turbidity level increases with increasing flow with the strongest relationship obtained for the dry season followed by the hot season. Also noticeable is the higher turbidity levels during the wet season than in the other seasons. The correspondence between high levels of both turbidity and flow for the Nile as reported in the present work is supported by earlier results for Atbara River, which brings more than 25 million tons of silt to the downstream during the wet season (Zaghloul et al. 2007). A wide scatter of the data points is noticeable in Fig. 5 for the wet season with the best-fit is achievable for August and September. To interpret this relationship, the cause of turbidity must be discussed which is simply the load of suspended solids in the river. A previous study for the Blue Nile in Khartoum State concluded that the turbidity is potentially a viable surrogate measurement for determining the concentrations of total suspended solids, with the analysis showing a strong positive linear relationship between the two parameters for the flood season (Musnad et al. 2015). Similar results were obtained for rivers in the United States and Sri Lanka (Ellison et al. 2010, Wickramaarachchi et al. 2013). The analysis of the relationship between turbidity and flow is very complicated because it is related to the cause of suspended solids mobilization and its importance which vary from site to another as stated by Göransson et al. (2013). Most of the studies dealing with the sediment yield on the Upper Blue Nile in Ethiopia indicate a space-time variation of sediment supply and transport (Easton et al. 2010, Tilahun et al. 2013, Ebabu et al. 2018). These studies also emphasize the importance of identifying the runoffcontributing areas and time for the investigation of the sedimentation dynamics and the discharge- 
sediment relationships. Since the majority of the Blue Nile flow is derived from Lake Tana and the runoff from the river catchment area in Ethiopia, the suspended solids mobilization should be understood in the context of significant increasing trends of wet-season runoff and sediment load in the Upper Blue Nile (Gebremicael et al. 2013), which also reflect in positive flow anomalies at Khartoum in the downstream (Fig. 3). Sediment load of a river influences the flood regime (Owens et al. 2005), and high sediment loads of floods complicate the performance of the flood regulation schemes (Vanmaercke et al. 2011).

\subsection{Urban nexus under flood and drought}

\subsubsection{Water-energy-food nexus in urban agriculture}

Many vegetables are grown under irrigation along the Nile banks to supply Khartoum State with its daily needs from these products. Farmers sell by themselves in nearby markets or through some local merchants (Abdalla et al. 2012). Transportation of these vegetables is facilitated by small or large vehicles that use different types of fuel; thus, the vegetables price is largely related to the oil prices in local and international markets, as explained by Headey and Fan (2008) who regards "the larger rise in oil prices - as a greater macroeconomic threat to the developing countries" and also by Esmaeili and Shokoohi (2011), who determined a positive relationship between the world crude oil prices on the world food prices and food security. Pumping of water from the Nile to the urban farms also needs energy, and different types of pumps are used like electrical pumps, which take electricity from the local grid, diesel pumps (Khalid 2003) as well as kinds of solar pumps in some schemes (Elzubeir 2016).

Food production at urban farms in Khartoum State is strongly linked to energy production through irrigation and transportation. During the flood season, and because of the high water level of the Nile, 
pumping of water may not be needed for farms adjacent to the Nile banks as pumps can be damaged by the floodwater. Contrarily, more pumping power for irrigation is needed in drought times to overcome the reduction of water level. Transportation of crops from the urban farms is affected greatly during the flood season, which is mostly associated with heavy rains in Khartoum State when roads become inundated due to deficient drainage system (Mahmoud et al. 2014, Mahmood et al. 2017) causing deterioration to transportation. Transportation cost increases greatly in this season and sometimes fails to supply markets thereabout with vegetables (Babiker 2017). Elbashir and Imam (2010) consider poor transportation as one of the major constrains to fruits and vegetables production in Sudan, including Khartoum State. Babiker (2017) estimates the irrigation cost in Khartoum State to represent $7.2-8.6 \%$ of the production cost of different vegetables whereas the transportation cost can represent $6.8-24.8 \%$ of the vegetables price in the market.

Using agricultural products as biomass to produce energy is a widely-known practice in Sudan. Biomass (especially fuelwood) has a high share of $87 \%$ of the total energy production, and the techniques for converting it to useful energy is easy (Omer 2005). Normally this type of energy production is practiced in the rural areas but is also available rarely in Khartoum State.

When the farmers were asked about the factors behind them perceiving declining crop production, they mentioned one or a mix of factors summarized as aridity and weed invasion ( $80 \%$ of the farms), poor soil in $66 \%$ of the farms, inferior seeds in $68 \%$ of the farms, and pest invasion in $52 \%$ of the farms. In times of drought, and due to direct competition between irrigation in urban agriculture and other high priority water use, such as drinking and domestic water uses, water availability can get quite limited (Maheshwari and Bristow 2016). Since urban agriculture in Khartoum can only be met by irrigation, the water demand has shown a steady increase (Schumacher et al. 2009). In drought-prone areas where application of fertilizers, pesticides and weed-killers is limited, droughts and land 
degradation increase weed infestations, and spread of infestation occurs under conditions of contaminated seeds and soils, eroding soils, improper disposal of weeds, etc. (Bussmann et al. 2016). It should also be mentioned that the Nile water can also transport deleterious types of weeds (e.g. hyacinth), which has become a major weed type (Beshir and Bennett 1984; Mailu 2001). Infestation and re-infestation by weeds and other aquatic vegetation types can also occur through irrigation and during flooding times (Khedr and El-Demerdash 1997).

One of the impacts of the 2006 flood was the inundation of farmlands on the river banks (Fig. 6a). The interviewed farmers on the impacts of sedimentation and river erosion mentioned that sedimentation has occurred on the western side of the Nile, resulting in an increase of the cultivation area while on the eastern bank of the Nile, bank erosion has led to loss of the farming lands. Such morphological changes could be attributed to fast human interventions, i.e. land-use and land-cover changes at the expense of the natural forest to agricultural lands and firewood trees (Woldesenbet et al. 2017), thus exacerbating the soil erosion process in the basin (Gebremicael et al. 2013) and increasing sedimentation process further downstream in reservoirs (Betrie et al. 2009, Alrajoula et al. 2016) and irrigations schemes (Ahmed 2009) in Sudan. Urban agriculture can be blessed by sediment deposits from the periodic floods of the Nile River since they represent an important source contributing significantly to soil fertility maintenance (Abdalla et al. 2012).

\subsubsection{Water-energy nexus in water treatment for domestic use}

During the flood event of 2006, the Nile water levels increased to the extent of inundating the banks, thus reaching the housing areas (Figs. $6 \mathrm{~b}$ and $6 \mathrm{c}$ ). The old intake of Bait Elmal WTP, which was established in 1927 by the British Administration to supply water to old Omdurman area, was well submerged during this flood event (Fig. 6d). However, observations reported during the river drought 
in April 2010 indicate remarkable morphological change in the Blue Nile, which manifested in the

452

453

454

455 appearance of several islands close to Bahir WTP on the Blue Nile (Figs. 7a and 7b).

Bait Elmal WTP is taken herein as an illustrative case study as it has been suffering from several environmental problems for several years now that can be ascribed to several drought- and flood-related factors in addition to human factors. These problems, discussed below, had implications for the water and energy nexus of the treatment plant.

a) Algal growth was observed on Nile during the drought of April 2010 drought year (Fig. 7c). Algal growth on Nile River has been clearly noticed in recent decades (Caspers 1977, Sinada and Abdel Karim 1984, Kheiralla et al. 2014). Accumulation of algal plankton in pumping and filtration units of Bait Elmal WTP leads to continuous failures and deteriorating efficiency.

b) Human interventions play a great role in changing the river morphology. Changing river channels in response to engineering works is well documented in the literature (Gregory 2006; Sun et al. 2012). The deposit of sediments has accumulated through the years, and now has led to changing the direction of water flow of the Nile and prevented it from entering the plant intake during the drought of April 2010. Therefore, a new intake was constructed (Figs. 7d and 7e) at a lower water level which entails more pumping energy needs. A plausible reason for this sediment accumulation is, for example, Shambat Bridge (Fig. 8a) that is situated on the Main Nile close to Bait Elmal station intake. It was constructed to connect two of the three main cities of Khartoum State, i.e. Omdurman with the Bahri areas. It has caused scouring, sediment deposition around the bridge piers, and changed the river cross-section by narrowing the river width near this area. Similar findings for the Nile demonstrate changes in the river resulting from the construction of bridges and other structures (Raslan 2010, Raslan and Salama 2015). 
c) Siltation has become the most pressing concern of the water supply mangers in Khartoum State. In fact, Bait Elmal WTP has been seriously affected by dramatic increase in the amount of sediment load into the Nile River that has led to clogging of pumps of water plants and resulting into constant malfunctioning of the plant (Fig. 8b). Since 2005, the station has been facing serious siltation problem which led to the closure of the station. Recently, due to this problem, the plant is functioning as a storage station only, taking treated water from Bahri WTP and distributing it to the old Omdurman area.

\subsubsection{Water-energy nexus in hydropower production}

In order to understand the pattern of hydropower generation from Roseires and Jebel Aulia dams during 2006-2010 (Fig. 9), one must first know the operation criteria of the two dams. The operation of dams in Sudan is normally aligned with the hydrologic year, thus starts on 1st June and ends on 31st May of the next year. The main purpose of Roseires Dam is to store water during the flood season to be used in large-scale irrigation during the dry season (MoIHES 1977). The following information on the operation of Rosieres Dam was obtained from MoIHPS (1968) and Basheer et al. (2018). Due to the high sediment load of the Blue Nile during the flood season, and to prolong the lifetime of the Dam, the reservoir is normally kept at the Minimum Operating Level (MOL) from the 1st of June until a date determined based on the following criteria: (1) September 1st if the dam inflow is below $350 \mathrm{MCM} / \mathrm{day}$ by this date, (2) A date between September 1st and September 26th in which the inflow falls from above to below $350 \mathrm{MCM} /$ day, or (3) September 26th if the inflow is still higher than $350 \mathrm{MCM} /$ day by this date. Thereafter, the reservoir is filled in 45 days and kept at the Full Supply Level (FSL) until the water demands exceed the river flow. The reservoir storage is used to meet the difference between the river flow and the water demands until May 31st. Hydropower generation from the dam is a by- 
product of the above operating rules. It is important to note that the above-mentioned rules of Roseires Dam have been changed in 2013 after the dam was heightened. On the other hand, the operation of Jebel Aulia Dam is based on target reservoir water levels as follows (Basheer and Elagib 2018): (1) MOL from June 1st until June 30th, (2) from July 1st to July 31st, the reservoir water level is raised from the MOL to $372.5 \mathrm{~m}$ asl, (3) $372.5 \mathrm{~m}$ asl from August 1st until August 31st, (4) from September 1st to September 30th, the reservoir water level is raised from the $372.5 \mathrm{~m}$ asl to FSL, (5) FSL from October 1st until March 14th, (6) from March 15th to May 15th, the reservoir water level is lowered from FSL to MOL, and (7) MOL from May 16th until May 31st. Hydropower generation from the Jebel Aulia Dam is a by-product of the above target reservoir water levels.

Figures 9a and 9b show energy generation from Roseires Dam. It is evident that the highest energy generation during 2006-2010 was in 2008 with around $1860 \mathrm{GWh}$ while the lowest was in 2010 with around $1580 \mathrm{GWh}$. Whereas the highest annual energy occurred in a year that follows the wettest year (i.e. 2007), the lowest happened in a year that comes after the driest year (i.e. 2009), as can also be compared with SDIs in Figs. $3 \mathrm{~b}$ and 3c. This attribute can be explained by the operating policy of the dam which follows the hydrologic year, resulting in filling and emptying the reservoir in two different calendar years as explained earlier. Fig. $9 \mathrm{~b}$ gives more insights into the impacts of drought and flood on energy generation through the probability of exceedance of daily energy generation from Roseires Dam for each of the years from 2006 to 2010. The lowest firm daily energy generation was recorded in 2010 (around $0.46 \mathrm{GWh}$ ) and the highest was found in 2007 (approximately 1.68 GWh). The years 2008 and 2009 had approximately similar firm energies of around $1.48 \mathrm{GWh} /$ day whereas 2006 recorded a value of $0.83 \mathrm{GWh} /$ day. The figure suggests that the turbines of Roseires Dam operated at their installed capacity (i.e. $280 \mathrm{MW}$ ) $47 \%$ of the year in $2008,45 \%$ of the year in $2007,40 \%$ of the year in $2006,36 \%$ of the year in 2010 , and $31 \%$ of the year in 2009 . Drought can be shown to influence 
the energy generation for instance in April 2010 in comparison to its counterparts in other years. In April 2010 , the total monthly energy amounted to around $20 \mathrm{GWh}$ whereas the firm daily energy generation was approximately $0.46 \mathrm{GWh}$, as compared to averages for the 2006-2010 levels, which amount to 47 and $1.2 \mathrm{GWH}$, respectively.

Regarding Jebel Aulia Dam, all years from 2006 to 2010 have approximately similar annual energy generation. This similarity is due to the regular flow of the White Nile because of the presence of the Sudd swamps in the upstream as explained in Section 2. The highest annual energy generation characterizes 2010 with around $0.063 \mathrm{GWh}$ while the lowest is an attribute of 2009 with roughly 0.056 GWh (Fig. 9c). Furthermore, as Fig. 9d shows, the installed capacity of the dam was never reached during 2006 to 2010, and a zero firm energy was noted within the same period. The latter characteristic occurred due to the regular total closure of all the outlets of Jebel Aulia Dam during the high flood period of the Blue Nile. This action is important to avoid any damage to the dam equipment as a result of the backflow from the Blue Nile into the White Nile (Sobeir 1983, Basheer and Elagib 2018).

\subsection{Possible mitigation and adaptation measures}

\subsubsection{Measures to secure water for domestic use}

Water treatment plants located on the Nile are designed mainly to remove turbidity and microorganisms. As noticed from the above results, turbidity is very high during the rainy season, thus creating high load in treatment plants all along the Nile where filtration is the main process of purification. High turbidity levels of Nile water during the wet season cause difficulties to drinking water treatment plants.

In rapid filtration systems, chemicals are used in coagulation/flocculation process to enhance the sedimentation of great percentages of suspended solids and in turn enable high rate of filtration. These 
chemicals, which are mostly aluminium salts imported from outside Sudan, are very expensive (Awad et al. 2013) and with debatable health impacts when used in large quantities (Ahmed 2004, World

544 Health Organization 2010). In slow filtration systems, high turbidity greatly reduces the plant efficiency due to the accumulation of suspended solids on filter surface, and also reduces the quality and quantity of the finished product. To avoid these effects and at the same time insure meeting the quality standards of the finished product, pre-treatment must be facilitated in all plants (rapid or slow filtration systems) to equalize the turbidity in the treatment plant influent water. Some common methods that can be used in designing water treatment plants are:

a) Plain sedimentation process (Pre-Sedimentation): The quality of water can be improved by holding 551 or storing the water undisturbed and without mixing long enough for larger particles to settle out or 552 sediment by gravity. The settled water can then be carefully removed and recovered by decanting, 553 ladling or other gentle methods that do not disturb the sedimented particles. In Sudan, multiple of 554 studies recommended plain sedimentation as a pre-treatment method in the Nile plants but the 555 implementation of such a measure has not yet started (Ahmed 2004, Musnad and Siyam 2016). 556 Studies elsewhere also showed the improvement of water quality and reduction in coagulants usage 557 when using sedimentation as a pre-treatment, especially in flood seasons (Ahamad et al. 2014, 558 Taghizadeh 2018).

559 b) Constructed wetlands or reed-beds: These techniques have a strong potential for application in the 560 small rural communities in the developing countries since they are less expensive, easily operated 561 and maintained (Kurzbaum et al. 2012). Their use in treating the river water and residual water has 562 been studied in a number of countries, and the problems associated with it have also been studied 563 (Borges et al. 2008). A research paper reported the high performance of a pilot-scale floating 564 constructed wetland in the Buriganga River in Bangladesh for the treatment of polluted water (Saeed 
et al. 2016). Another study proved the high efficiency of this method in reducing pollutants load in relatively low-polluted water like storm runoff, i.e. similar to river water quality (Vincent et al. 2018). Nevertheless, the employment of these techniques in purifying the river water for improving the drinking water quality is still uncommon (Kurzbaum et al. 2012). The use of this method could reduce the high turbidity levels on the Nile water by feeding the water plant intakes from constructed horizontal flow wetlands or reed beds beside the Nile - as branched shallow canals fitted with flow regulators at entrances like weirs or sluice gates - to reduce the scouring velocity. The method needs to be tested on a pilot scale before application.

c) Natural coagulants: They have been investigated by research to deal with the problems caused by the chemical coagulants (Saritha et al. 2017). Simple natural materials like types of soils or some species of plants were tested as coagulant elsewhere and gave very good results (Jahn and Dirar 1979, Birima et al. 2013, Ramavandi 2014). Research in this point can lead to great achievement in reducing treatment cost and enhancing the finished product quality.

\subsubsection{Measures to secure food within urban agriculture}

The capacity of the Nile countries to address current and future impacts of climate change needs to be enhanced (UNEP 2015). Dubbeling and De Zeeuw (2011) stated that the urban farmers will be hit hardest by climate-related impacts because they are often located in the most vulnerable parts of the cities and lacking the capacity to adapt. Based on the present results of the farmers' interview for Khartoum State, $88 \%$ of the respondents mentioned that they cultivate earlier and adopt crop rotation. The former measure can be interpreted as a useful strategy during the short-term rainy season Nile flows to avoid heavy use of energy for pumping and, additionally, the damage to crops induced during the flood events, if there are any. Such an interpretation can be asserted by the least number of 
respondents (only 12\%) who delay cultivation. The second most iterated adaptation strategy by the farmers was frequent weeding times ( $68 \%$ of the respondents) followed by soil conservation, which was mentioned by $62 \%$ of the farmers. Among the 50 interviewed farmers, $48 \%$ indicated that they cultivate early maturing crops. This strategy could also be understood to make use of the advantage of early cultivation as discussed above. Intercropping and use of fertilizations and pesticides are only adopted by $20 \%$ and $16 \%$ of the farmers respectively.

\subsubsection{Measures to secure energy}

596 Despite that hydropower generation from Rosieres and Jebel Aulia dams is a by-product and not the 597 main target of the dams, the impact of hydrological extremes on hydropower can be profoundly 598 observed. The operation of the two dams is closely related to, and limited by, the annual cycle of the Nile flows. Several studies have shown that basin-wide coordination of dam operation in the Nile Basin can increase hydropower generation and reduce water supply shortages considerably (Wheeler et al. 2016, Digna et al. 2018). The Grand Ethiopian Renaissance Dam (GERD: DoP (2015)), an under construction multi-year storage dam on the Blue Nile in Ethiopia, is expected to be completed in 2019. The dam is expected to regulate the flow of the Blue Nile and to reduce the sediment load that passes to Sudan. Several studies recommend operating all the Sudanese dams on the Blue Nile, including Roseires Dam, at their FSLs all the year round due to the decrease in sediment load and to maximize the energy generation (MoWRI Egypt 2014, Wheeler et al. 2016, Basheer et al. 2018). Basheer et al.

607 (2018) recommend the installation of turbines with higher capacity in Roseires Dam to exploit the 608 increase in energy potential due to both the heightening of the dam and the anticipated regulation effect 609 of the GERD. Basheer and Elagib (2018) recommend modifying the operation of Jebel Aulia Dam after 
the construction of the GERD because the original operation takes into account the natural flow regime

611 of the Blue Nile.

In light of the above recommendations, there is now doubt that modifying the operation of

613 Roseires and Jebel Aulia dams would be essential in the near future to optimize the use of water for

614 hydro-energy generation. It is worth mentioning, however, that there are also fears of adverse effects 615 of the GERD in the form of: (1) reduced fertility of the soils downstream due to the expected attenuation 616 of sediment load (Alrajoula et al. 2016) and (2) decreased areas of recession agriculture (Mohammed 617 2015, Basheer et al. 2018).

\section{Conclusions}

As concluded by Engström et al. (2017), a full climate, land, energy and water (CLEW) nexus approach to assessing the inter-linked impacts, trade-offs and co-benefits from interventions in urban resource systems holds a promising support for increased resource efficiency through integrated decision making. In the present study, an urban-level WEF nexus is analyzed under conditions of drought and flood in the Nile by drawing upon the case study of Khartoum State. The results presented herein for Khartoum State, which encompasses the confluence of the White Nile and the Blue Nile, suggest several indicators to explain the interactions between, and the impacts on, the water, energy and food systems in association with drought and flood hazards within the urban environment. Floods and 628 droughts determine the water environment, i.e. the water amount and quality, which influence the integrated relationship between the WEF systems. Both environmental hazards, and in turn the water environment, impose risks to water treatment and supply. Activities within the urban agriculture sector, such as land availability for farming, pumping energy for irrigation, and water for food production, are 
impacted both positively and negatively by floods and droughts, as these events can largely determine the facets of urban agriculture, such as availability of land for cultivation, energy requirements for irrigation, productivity levels for food supply to the capital, and energy production from agricultural residues. The water environment under drought and flood times brings about cons and pros to energy production for Khartoum State. While high floods can give rise to hydropower generation due to water abundance, they can also pose difficulties to it through the increased levels of sediment loads, which are transferred to hydropower dams through runoff generated in highly degraded lands and, in turn, erosive soils. Droughts, on the other hand, induce enormous shortages in hydropower generation. In terms of measures to secure the WEF resources, it has also been shown that cons and pros would also be anticipated from managing the nexus. For instance, dams constructed to secure hydro-energy and regulate the sediment load that affects the water security could, on the other hand, pose risks to agricultural activities downstream due to anticipated less fertility of the lands. Hence, the results of the present research confirm the conclusion drawn by $\mathrm{Hu}$ et al. (2018) that for integrated and efficient resource policy implementations, research aiming at quantifying and analyzing the integrated and cooperative management of hydropower generation and water supply of reservoir systems is quite relevant.

This study was an attempt of analyzing the resource linkages toward understanding the nexus of a city within the Nile Basin. It is believed that other dimensions of the urban nexus could be further investigated in the future. For example, the industrial and economic dimensions of the nexus under scenarios of future climate change and consequent floods and drought constitute rich areas of research. The urban institutional role in operationalizing the nexus is another area worth investigation. As a measure to adapt to climate change, quantification of the benefits from operationalizing the huge and expensive amount of natural resources consumed and the wastes resulting from this consumption could 
655 also be carried out, considering the lessons learnt in the pilot study of a developed urban city 656 (Gondhalekar and Ramsauer 2017).

657

658

\section{Acknowledgement}

659 Many thanks go to the German Academic Exchange Service (DAAD) for funding the MSc studies of 660 Mrs. Gore (co-author), to Prof. Gamal Abdu, Director of the Water Research Centre at University of 661 Khartoum who provided Mrs. Gore for hosting her research stay within the centre, and to Eng. Yasin for guiding 662 her filed trips in Khartoum.

663

\section{References}

665

666

667

668

669

670

671

672

673

674

675

676

677

Abbas HB, Routray JK (2013) A semi-quantitative risk assessment model of primary health care service interruption during flood: Case study of Aroma locality, Kassala State of Sudan. Int J Disaster Risk Reduct 6:118-128. doi: 10.1016/j.ijdrr.2013.10.002

Abdalla S, Beckedorf A, Blanchon D, et al (2010) Thirsty Capital : Urban Growth, Water Management and Infrastructure Investments in Khartoum. UGEC Viewpoints 39-43

Abdalla SB, Predotova M, Gebauer J, Buerkert A (2012) Horizontal nutrient flows and balances in irrigated urban gardens of Khartoum, Sudan. Nutr Cycl Agroecosystems 92:119-132. doi: 10.1007/s10705-011-9476-7

Ahamad KU, Sonowal DB, Kumar V, et al (2014) Study on the impact of pre-sedimentation and consequently optimization of alum dose in water treatment process. Water Pract Technol 9:417429. doi: $10.2166 /$ wpt.2014.046

Ahmed A. (2009) Gezira Scheme irrigation system performance after 80 years of operation. In: International Conference on Water, Environment, Energy and Society. New Delhi 
678

679

680

681

682

683

684

685

686

687

688

689

690

691

692

693

694

695

696

697

698

699

700

Ahmed N (2004) Assessment of the Performance of Mogran Water Treatment Plant During Flood Season. University of Khartoum

Al-Saidi M, Elagib N (2017) Towards understanding the integrative approach of the water, energy and food nexus. Sci Total Environ 574:1131-1139. doi: 10.1016/j.scitotenv.2016.09.046

Al-Saidi M, Elagib NA, Ribbe L, et al (2017) Water-Energy-Food Security Nexus in the Eastern Nile Basin : Assessing the Potential of Transboundary Regional Cooperation. In: Abdul Salam P, Shrestha S, Pandey VP, Anal AK (eds) Water-Energy-Food Nexus: Principles and Practices. John Wiley \& Sons, American Geophysical Union

Al-Saidi M, Hefny A (2018) Institutional Arrangements for Beneficial Regional Cooperation on Water, Energy and Food Priority Issues in the Eastern Nile Basin. J Hydrol 562:821-831. doi: 10.1016/j.jhydrol.2018.05.009

Alrajoula MT, Al Zayed IS, Elagib NA, Hamdi MR (2016) Hydrological, socio-economic and reservoir alterations of Er Roseires Dam in Sudan. Sci Total Environ 566-567:938-948. doi: 10.1016/j.scitotenv.2016.05.029

ANDRITZ Hydro (2013) Hydromatrix: Jebel Aulia - Sudan. Linz

Awad M, Li F, Wang H (2013) An Investigative Study on Natural Soil. J Appl Sci Environ Sanit $8: 53-60$

Babiker AAG (1982) Urbanization and desertification in the Sudan with special reference to Khartoum. GeoJournal 6:69-76. doi: 10.1007/BF00446596

Babiker MHO (2017) Production and Marketing of Vegetables Crops in Khartoum State, Sudan. Int J Agric Innov Res 6:2319-1473

Basheer M, Elagib NA (2018) Sensitivity of Water-Energy Nexus to dam operation: A Water-Energy Productivity concept. Sci Total Environ 616-617:918-926. doi: 10.1016/j.scitotenv.2017.10.228 
Basheer M, Wheeler KG, Ribbe L, et al (2018) Quantifying and evaluating the impacts of cooperation in transboundary river basins on the Water-Energy-Food nexus: The Blue Nile Basin. Sci Total Environ 630:1309-1323. doi: 10.1016/j.scitotenv.2018.02.249

Beshir MO, Bennett FD (1984) Biological control of water hyacinth on the White Nile, Sudan. Agriculture Canada, Ottawa, Canada, pp 491-496

Betrie GD, Mohamed YA, Van Griensven A, et al (2009) Modeling of soil erosion and sediment transport in the Blue Nile Basin using the Open Model Interface Approach. In: Improved Water and Land Management in the Ethiopian Highlands: Its Impact on Downstream Stakeholders Dependent on the Blue Nile. Addis Ababa, pp 132-140

Birima AH, Hammad HA, Desa MNM, Muda ZC (2013) Extraction of natural coagulant from peanut seeds for treatment of turbid water. In: IOP Conference Series: Earth and Environmental Science. IOP Publishing

Boadi K, Kuitunen M, Raheem K, Hanninen K (2005) Urbanisation Without Development: Environmental and Health Implications in African Cities. Environ Dev Sustain 7:465-500. doi: $10.1007 / \mathrm{s} 10668-004-5410-3$

Bordi I, Fraedrich K, Sutera A (2009) Observed drought and wetness trends in Europe: An update. Hydrol Earth Syst Sci 13:1519-1530. doi: 10.5194/hess-13-1519-2009

Borges AKP, Tauk-Tornisielo SM, Domingos RN, De Angelis DDF (2008) Performance of the constructed wetland system for the treatment of water from the Corumbataí River. Brazilian Arch Biol Technol 51:1279-1286. doi: 10.1590/S1516-89132008000600024

Bussmann A, Elagib NA, Fayyad M, Ribbe L (2016) Sowing date determinants for Sahelian rainfed agriculture in the context of agricultural policies and water management. Land use policy 52:316-328. doi: 10.1016/j.landusepol.2015.12.007 
Caspers H (1977) The nile, biology of an ancient river. Editor: Julian Rzóska — Monographiae Biologicae (editor J. Illies) Volume 29. - With 101 figs., 18 tabl., 1 map, 420 pp. — The Hague: Dr. J. Junk B. V., Publishers 1976. ISBN 906193081 2. Hfl. 120.—. Int Rev der gesamten Hydrobiol und Hydrogr 62:834-835. doi: 10.1002/iroh.1977.3510620622

Conway D (1997) A water balance model of the Upper Blue Nile in Ethiopia. Hydrol Sci J 42:265286. doi: $10.1080 / 02626669709492024$

Conway D, Hulme M (1993) Recent fluctuations in precipitation and runoff over the Nile sub-basins and their impact on main Nile discharge. Clim Change 25:127-151. doi: 10.1007/BF01661202

Davies HRJ, Walsh RPD (1997) Historical Changes in the Flood Hazard at Khartoum, Sudan: Lessons and Warnings for the Future. Singap J Trop Geogr 18:123-140. doi: 10.1111/14679493.00012

Degefu MA, Bewket W (2014) Variability and trends in rainfall amount and extreme event indices in the Omo-Ghibe River Basin, Ethiopia. Reg Environ Chang 14:799-810. doi: 10.1007/s10113013-0538-z

Dewan TH (2015) Societal impacts and vulnerability to floods in Bangladesh and Nepal. Weather Clim Extrem 7:36-42. doi: 10.1016/j.wace.2014.11.001

Digna RF, Castro-Gama ME, van der Zaag P, et al (2018) Optimal operation of the Eastern Nile System using Genetic Algorithm, and benefits distribution of water resources development. Water (Switzerland) 10:. doi: 10.3390/w10070921

DIU (2016) Roseires Heightening Project. In: Minist. Water Resour. Electr. Sudan. http://www.roseiresdam.gov.sd/en/raising_project.htm. Accessed 27 Jan 2019

DoP (2015) Agreement on Declaration of Principles between The Arab Republic of Egypt, The Federal Democratic Republic of Ethiopia And The Republic of the Sudan On The Grand 
Du W, FitzGerald GJ, Clark M, Hou X-Y (2010) Health Impacts of Floods. Prehosp Disaster Med 25:265-272. doi: 10.1017/S1049023X00008141

Dubbeling M, De Zeeuw H (2011) Urban Agriculture and Climate Change Adaptation: Ensuring Food Security Through Adaptation BT - Resilient Cities. In: Otto-Zimmermann K (ed). Springer Netherlands, Dordrecht, pp 441-449

Easton ZM, Fuka DR, White ED, et al (2010) A multi basin SWAT model analysis of runoff and sedimentation in the Blue Nile, Ethiopia. Hydrol Earth Syst Sci 14:1827-1841. doi: $10.5194 /$ hess-14-1827-2010

Ebabu K, Tsunekawa A, Haregeweyn N, et al (2018) Analyzing the variability of sediment yield: A case study from paired watersheds in the Upper Blue Nile basin, Ethiopia. Geomorphology 303:446-455. doi: 10.1016/j.geomorph.2017.12.020

El Nour, Balla AH (1989) The relationship between urbanization and socio-economic development in the Sudan. GeoJournal 18:369-377. doi: 10.1007/BF00772691

Elagib NA (2011) Evolution of urban heat island in Khartoum. Int J Climatol 31:1377-1388. doi: 10.1002/joc. 2159

Elagib NA (2009) Assessment of drought across central Sudan using UNEP dryness ratio. Hydrol Res 40:481. doi: 10.2166/nh.2009.016

Elagib NA, Elhag MM (2011) Major climate indicators of ongoing drought in Sudan. J Hydrol 409:612-625. doi: 10.1016/j.jhydrol.2011.08.047

Elagib NA, Musa AA, Sulieman HM (2017) Socio-hydrological Framework of Farmer-Drought Feedback: Darfur as a Case Study. In: Abdalla O, Kacimov A, Chen M, et al. (eds) Water Resources in Arid Areas: The Way Forward. Springer International Publishing, Cham, pp 461- 
771 Elbashir H, Imam M (2010) Status Report on Fruits and Vegetables Production and Processing Industry in Sudan

773

774

775

Ellison C, Kiesling R, Fallon J (2010) Correlating streamflow, turbidity, and suspended-sediment concentration in minnesota's wild rice river. In: 2nd Joint Federal Intragency Conference. Las Vegas, pp 1-12

Elzubeir AO (2016) Solar Energy in Northern State (Sudan): Current State and Prospects. Am J Mod Energy 2:31-37. doi: 10.11648/j.ajme.20160205.12

Engström RE, Howells M, Destouni G, et al (2017) Connecting the resource nexus to basic urban service provision - with a focus on water-energy interactions in New York City. Sustain Cities Soc 31:83-94. doi: 10.1016/j.scs.2017.02.007

Esmaeili A, Shokoohi Z (2011) Assessing the effect of oil price on world food prices: Application of principal component analysis. Energy Policy 39:1022-1025. doi: 10.1016/j.enpol.2010.11.004

FAO (2014) The Water-Energy-Food Nexus - A new approach in support of food security and sustainable agriculture. Rome

Gebremicael TG, Mohamed YA, Betrie GD, et al (2013) Trend analysis of runoff and sediment fluxes in the Upper Blue Nile basin: A combined analysis of statistical tests, physically-based models and landuse maps. J Hydrol 482:57-68. doi: 10.1016/j.jhydrol.2012.12.023

Gondhalekar D, Ramsauer T (2017) Nexus City: Operationalizing the urban Water-Energy-Food Nexus for climate change adaptation in Munich, Germany. Urban Clim 19:28-40. doi: 10.1016/j.uclim.2016.11.004

Göransson G, Larson M, Bendz D (2013) Variation in turbidity with precipitation and flow in a regulated river system-river Göta Älv, SW Sweden. Hydrol Earth Syst Sci 17:2529-2542. doi: 
794 Gregory KJ (2006) The human role in changing river channels. Geomorphology 79:172-191. doi: 10.1016/j.geomorph.2006.06.018

796

797

798

799

800

801

802

803

804

805

806

807

808

809

810

811

812

813

814

815

Headey D, Fan S (2008) Anatomy of a crisis: The causes and consequences of surging food prices. Agric Econ 39:375-391. doi: 10.1111/j.1574-0862.2008.00345.x

HEC (2000) Hydrologic Modeling System HEC-HMS Technical Reference Manual. Washington

Hrdinka T, Novický O, Hanslík E, Rieder M (2012) Possible impacts of floods and droughts on water quality. J Hydro-Environment Res 6:145-150. doi: 10.1016/j.jher.2012.01.008

Hu MC, Huang T, Yu HL, Tung CP (2018) Stochastic competitive analysis of hydropower and water supplies within an energy-water nexus. Stoch Environ Res Risk Assess 32:2761-2769. doi: $10.1007 / \mathrm{s} 00477-017-1500-2$

Jahn SAA, Dirar H (1979) Studies on Natural Water Coagulants in the Sudan, With Special Reference To Moringa Oleifera Seeds. Water SA 5:90-97

Jarvis A, Reuter H, Nelson A, Guevara E (2008) Hole-filled SRTM for the globe Version 4. In: CGIAR-CSI SRTM 90m Database. http://srtm.csi.cgiar.org. Accessed 30 Dec 2018 Kanji G (2006) 100 Statistical tests

Khalid N (2003) Performance of small irrigation pumps in Khartoum State. University of Khartoum

Khedr AHA, El-Demerdash MA (1997) Distribution of aquatic plants in relation to environmental factors in the Nile Delta. Aquat Bot 56:75-86. doi: 10.1016/S0304-3770(96)01090-X

Kheiralla K, Eshag A, Elzien S, et al (2014) Seasonal Variation of Algae Types, Counts and Their Effect on Purified Water Quality Case Study: Al-Mogran and Burri Plants, Khartoum State,Sudan. J Biodivers Endanger Species 2:2-5. doi: 10.4172/2332-2543.1000122

Kundzewicz ZW, Budhakooncharoen S, Bronstert A, et al (2003) Coping with variability and change: 
Kundzewicz ZW, Mata LJ, Arnell NW, et al (2007) Freshwater resources and their management. In: Parry ML, Caziani OF, Palutikof JP, et al. (eds) Climate Change 2007: Impacts, Adaptation and Vulnerability. Contribution of Working Group II to the Fourth Assessment Report of the Intergovernmental Panel on Climate Change. Cambridge University Press, Cambridge, pp 173210

Kurzbaum E, Kirzhner F, Armon R (2012) Improvement of water quality using constructed wetland systems. Rev Environ Health 27:59-64. doi: 10.1515/reveh-2012-0005

Landsberg HE (1982) Climatic Aspects of Droughts. Bull Am Meteorol Soc 63:593-597

Leathers DJ, Grundstein AJ, Ellis AW (2000) Growing season moisture deficits across the northeastern United States. Clim Res 14:43-55

Lewis J, Eads R (2009) Implementation Guide for Turbidity Threshold Sampling: Principles, Procedures, and Analysis

Maheshwari B, Bristow KL (2016) Peri-urban water, agriculture and urbanisation. Agric Water Manag 176:263-265. doi: 10.1016/j.agwat.2016.09.009

Mahmood MI, Elagib NA, Horn F, Saad SAG (2017) Lessons learned from Khartoum flash flood impacts: An integrated assessment. Sci Total Environ 601-602:1031-1045. doi: 10.1016/j.scitotenv.2017.05.260

Mahmoud WH, Elagib NA, Gaese H, Heinrich J (2014) Rainfall conditions and rainwater harvesting potential in the urban area of Khartoum. Resour Conserv Recycl 91:89-99. doi: 10.1016/j.resconrec.2014.07.014

Mailu AM (2001) Preliminary assessment of the social, economic and environmental impacts of water hyacinth in the Lake Victoria Basin and the status of control. In: Biological and integrated 
control of water hyacinth: Eichhornia crassipes. Proceedings of the Second Meeting of the Global Working Group for the Biological and Integrated Control of Water Hyacinth, Beijing, China, 9-12 October 2000. Australian Centre for International Agricultural Research (ACIAR), Canberra, pp 130-139

Mawdsley J, Petts GE, Walker S (1994) Assessment of drought severity. Institute of Hydrology

Merz B, Kreibich H, Schwarze R, Thieken A (2010) Review article" Assessment of economic flood damage". Nat Hazards Earth Syst Sci 10:1697-1724. doi: 10.5194/nhess-10-1697-2010

Mishra AK, Singh VP (2010) A review of drought concepts. J Hydrol 391:202-216. doi:

$$
\text { 10.1016/j.jhydrol.2010.07.012 }
$$

Mohammed K (2015) Ma'akhz wathiqat i'lan almabade' hawla sad alnahda men almontalaq alilmy alhandasy [Reservations on the Declaration of Principles on GERD from a technical point of view]. In: Sudacon. http://www.sudacon.net/2015/04/blog-post_6.html. Accessed 17 Nov 2018

MoIHES (1977) Blue Nile Waters Study Phase IA: Availability and Use of Blue Nile Water. Khartoum

MoIHPS (1968) Regulation Rules for the Working of the Reservoirs at Roseires and Sennar on the Blue Nile

MoWRI Egypt (2014) Assessment of the Impact of the Grand Ethiopian Renaissance Dam on Egypt.

$$
\text { Cairo }
$$

Mu Q, Zhao M, Running S (2011) Improvements to a MODIS global terrestrial evapotranspiration algorithm. Remote Sens Environ 115:1781-1800. doi: 10.1016/j.rse.2011.02.019

Musnad M, Siyam AM, Bashar KE (2015) The Relationship between Turbidity and Total Suspended Solids in the Blue Nile River at Khartoum. Water Sci Eng J 8:41-50

Musnad MM, Siyam AM (2016) Using pre-sedimentation tank to mitigate high turbidity in water 
treatment plants. Noor Publ

863

864

865

866

867

868

869

870

871

872

873

874

875

876

877

878

879

880

881

882

883

884

Nalbantis I, Tsakiris G (2009) Assessment of Hydrological Drought Revisited. Water Resour Manag 23:881-897. doi: 10.1007/s11269-008-9305-1

NBI (2012) State of the River Nile Basin 2012. Entebbe

Novella N, Thiaw W (2013) African rainfall climatology version 2 for famine early warning systems. J Appl Meteorol Climatol 52:588-606. doi: 10.1175/JAMC-D-11-0238.1

Omer AM (2005) Biomass energy potential and future prospect in Sudan. Renew Sustain Energy Rev 9:1-27. doi: 10.1016/j.rser.2003.12.011

Owens PN, Batalla RJ, Collins AJ, et al (2005) Fine-grained sediment in river systems: environmental significance and management issues. River Res App1 21:693-717. doi: $10.1002 /$ rra. 878

Paeth H, Fink AH, Pohle S, et al (2011) Meteorological characteristics and potential causes of the 2007 flood in sub-Saharan Africa. Int J Climatol 31:1908-1926. doi: 10.1002/joc.2199

Posthumus H, Morris J, Hess TM, et al (2009) Impacts of the summer 2007 floods on agriculture in England. J Flood Risk Manag 2:182-189. doi: 10.1111/j.1753-318X.2009.01031.x

Ramavandi B (2014) Treatment of water turbidity and bacteria by using a coagulant extracted from Plantago ovata. Water Resour Ind 6:36-50. doi: 10.1016/j.wri.2014.07.001

Rao AR, Voeller TL (1997) Development and Testing of Drought Indicators. Water Resour Manag 11:119-136. doi: 10.1023/A:1007933725122

Raslan Y, Salama R (2015) Development of Nile River islands between Old Aswan Dam and new Esna barrages. Water Sci 29:77-92. doi: 10.1016/j.wsj.2015.03.003

Raslan YM (2010) Human Impacts on Nile River Morphology

Roidt M, Avellán T (2019) Learning from integrated management approaches to implement the 
Saeed T, Paul B, Afrin R, et al (2016) Floating constructed wetland for the treatment of polluted river water: A pilot scale study on seasonal variation and shock load. Chem Eng J 287:62-73. doi: 10.1016/j.cej.2015.10.118

889

890

891

892

Samimi C, Fink AH, Paeth H (2012) The 2007 flood in the Sahel: Causes, characteristics and its presentation in the media and FEWS NET. Nat Hazards Earth Syst Sci 12:313-325. doi: 10.5194/nhess-12-313-2012

Saritha V, Srinivas N, Srikanth Vuppala N V. (2017) Analysis and optimization of coagulation and flocculation process. Appl Water Sci 7:451-460. doi: 10.1007/s13201-014-0262-y

Savenije HHG (1995) Recent extreme floods in Europe and the USA; challenges for the future. Phys Chem Earth 20:433-437. doi: 10.1016/S0079-1946(96)00001-8

Schumacher J, Luedeling E, Gebauer J, et al (2009) Spatial expansion and water requirements of urban agriculture in Khartoum, Sudan. J Arid Environ 73:399-406. doi: 10.1016/j.jaridenv.2008.12.005

Shukla S, Wood AW (2008) Use of a standardized runoff index for characterizing hydrologic drought. Geophys Res Lett 35:1-7. doi: 10.1029/2007GL032487

Sinada F, Abdel Karim AG (1984) A quantitative study of the phytoplankton in the Blue and White Niles at Khartoum. Hydrobiologia 110:47-55. doi: 10.1007/BF00025775

Sobeir SE (1983) Gebel Aulia dam and reservoir. Khartoum

Stamou A, Rutschmann P (2018) Pareto Optimization of Water Resources Using the Nexus Approach. Water Resour Manag. doi: 10.1007/s1 1269-018-2127-x

Sudan Population (2018) World Population Review. http://worldpopulationreview.com/countries/sudan/. Accessed 11 Nov 2018 
908

909

910

911

912

913

914

Sultana P, Thompson PM (2018) Effects of flood control and drainage on fisheries in Bangladesh and the design of mitigating measures. Regul Rivers Res Manag 13:43-55. doi: 10.1002/(SICI)10991646(199701)13:1<43::AID-RRR423>3.0.CO;2-K

Sun Z, Huang Q, Opp C, et al (2012) Impacts and Implications of Major Changes Caused by the Three Gorges Dam in the Middle Reaches of the Yangtze River, China. Water Resour Manag 26:3367-3378. doi: 10.1007/s11269-012-0076-3

Susfalk RB, Fitzgerald B, Knust AM (2008) Characterization of turbidity and total suspended solids in the Upper Carson River, Nevada

Sutcliffe J, Parks Y (1999) The Hydrology of the Nile. The International Association of Hydrological Science, Wallingford

Sutcliffe J V., Dugdale G, Milford JR (1989) The sudan floods of 1988. Hydrol Sci J 34:355-364. doi: $10.1080 / 02626668909491339$

Taghizadeh mohammad mehdi (2018) Pre-sedimentation tank effects on water treatment unit operation. EQA - Int J Environ Qual 27:. doi: 10.6092/issn.2281-4485/7804

Taye MT, Willems P, Block P (2015) Implications of climate change on hydrological extremes in the Blue Nile basin: A review. J Hydrol Reg Stud 4:280-293. doi: 10.1016/j.ejrh.2015.07.001

Tekleab S, Mohamed Y, Uhlenbrook S, Wenninger J (2013) Hydrologic responses to land cover change: the case of Jedeb mesoscale catchment, Abay/Upper Blue Nile basin, Ethiopia. Hydrol Process 28:5149-5161. doi: 10.1002/hyp.9998

Tilahun SA, Guzman CD, Zegeye AD, et al (2013) An efficient semi-distributed hillslope erosion model for the subhumid Ethiopian Highlands. Hydrol Earth Syst Sci 17:1051-1063. doi: 10.5194/hess-17-1051-2013

UNEP (2015) Climate Change Adaptation Capacities in the Nile River Basin 
931

932

933

934

935

936

937

938

939

940

941

942

943

944

945

946

947

948

949

950

951

952

953

Vanmaercke M, Poesen J, Maetens W, et al (2011) Sediment yield as a desertification risk indicator. Sci Total Environ 409:1715-1725. doi: 10.1016/j.scitotenv.2011.01.034

Vincent G, Shang K, Zhang G, et al (2018) Plant growth and nutrient uptake in treatment wetlands for water with low pollutant concentration. Water Sci Technol 77:1072-1078. doi: $10.2166 /$ wst.2017.624

Walker S, Smithers HA (1995) Recent advances in drought management with particular reference to northwest England. In: Modelling and Management of Sustainable Basin-scale Water Resource Systems. IAHS Publ, Boulder, pp 107-116

Walsh RPD, Davies HRJ, Musa SB (1994) Flood Frequency and Impacts at Khartoum since the Early Nineteenth Century. Geogr J 160:266-279. doi: 10.2307/3059609

Wheeler K, Robinson C, Bark R (2018) Modelling to bridge many boundaries: the Colorado and Murray-Darling River basins. Reg Environ Chang. doi: 10.1007/s10113-018-1304-z

Wheeler KG, Basheer M, Mekonnen Z, et al (2016) Cooperative filling approaches for the Grand Ethiopian Renaissance Dam. Water Int 8060:1-24. doi: 10.1080/02508060.2016.1177698

Wickramaarachchi TN, Ishidaira H, Wijayaratna TMN (2013) Streamflow, Suspended Solids, and Turbidity Characteristics of the Gin River, Sri Lanka. Eng J Inst Eng Sri Lanka 46:43-51. doi: 10.4038/engineer.v46i4.6809

Woldesenbet TA, Elagib NA, Ribbe L, Heinrich J (2017) Hydrological responses to land use/cover changes in the source region of the Upper Blue Nile Basin, Ethiopia. Sci Total Environ 575:724 741. doi: 10.1016/j.scitotenv.2016.09.124

Worku G, Teferi E, Bantider A, Dile YT (2018) Observed changes in extremes of daily rainfall and temperature in Jemma Sub-Basin, Upper Blue Nile Basin, Ethiopia. Theor Appl Climatol. doi: $10.1007 / \mathrm{s} 00704-018-2412-\mathrm{x}$ 
954 World Health Organization (2010) Aluminium in drinking-water: background document for 955 development of WHO Guidelines for drinking-water quality

956 Zaghloul S, El-Moattassem M, Rady A (2007) The hydrological interactions between Atbara River 957 and the Main Nile at the confluence area. In: the International Congress of River Basin 958 Management. Antalya, pp 787-799

959 Zagona E, Fulp T, Shane R, et al (2001) Riverware : a Generalized Tool for Complex Reservoir $960 \quad$ System Modeling. J Am Water Resour Assoc 37:913-929

961 Zhang C, Chen X, Li Y, et al (2018) Water-energy-food nexus: Concepts, questions and 962 methodologies. J Clean Prod 195:625-639. doi: 10.1016/j.jclepro.2018.05.194 


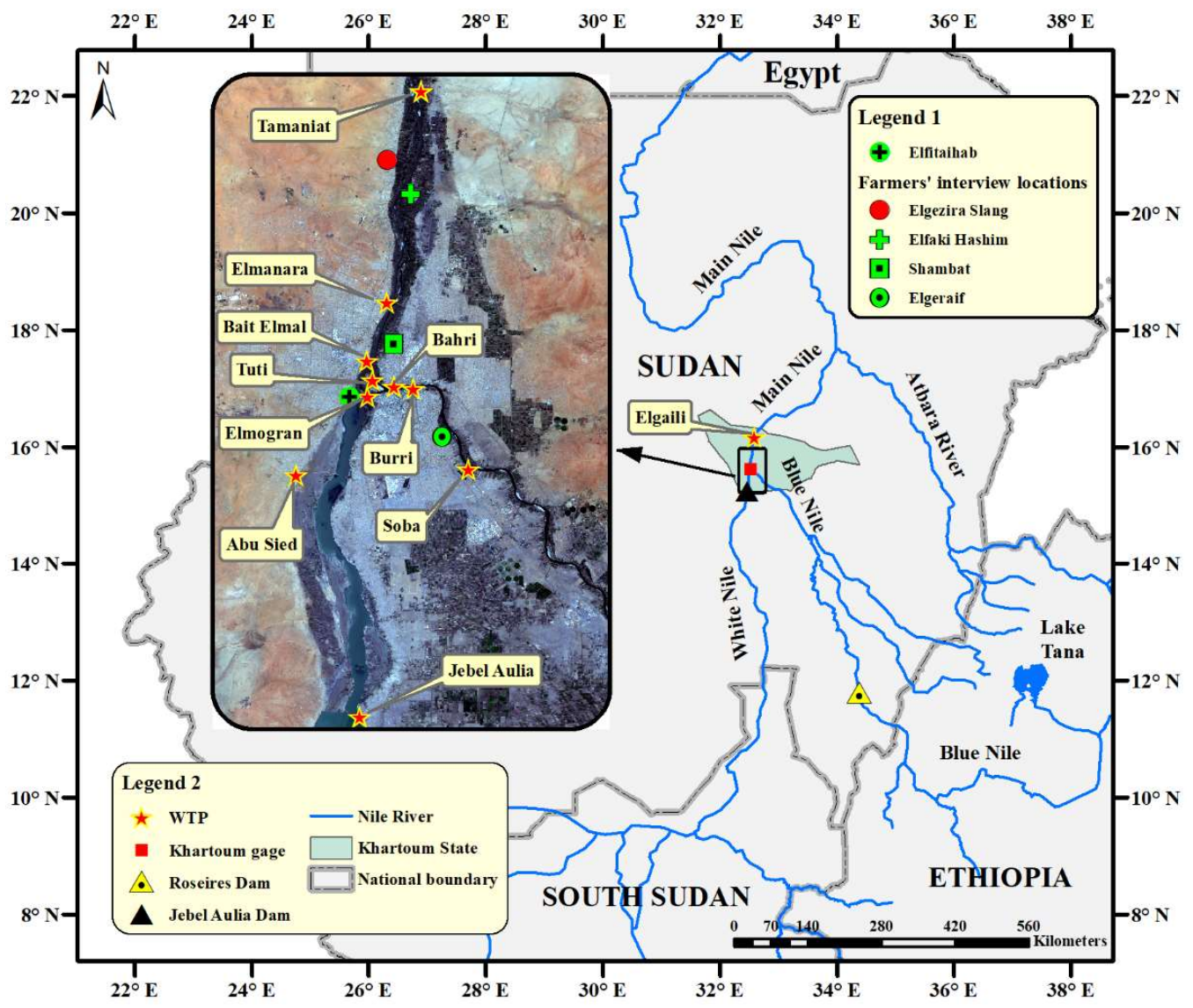

Fig. 1 Map of Sudan showing the study area (the capital of Sudan, Khartoum State), the Nile River, locations of respondent farmers to the questionnaire, and the water treatment plants (WTP) and two hydropower dams serving the capital 


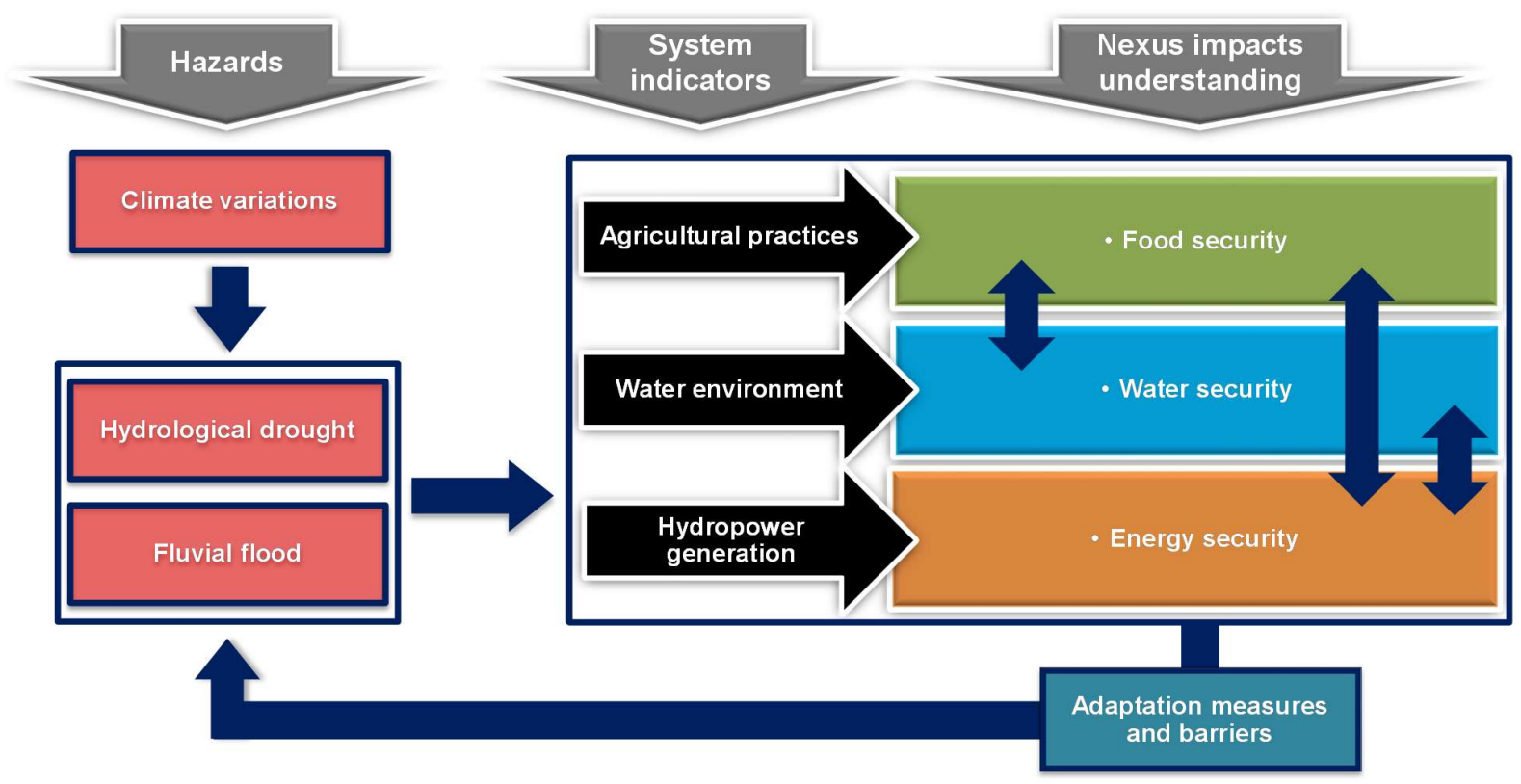

Fig. 2 Conceptual framework of urban water-energy-food (WEF) nexus under environmental hazards in the Nile as investigated in the present study. The up-down arrows refer to nexus or categories to be integrated with each other in the present study
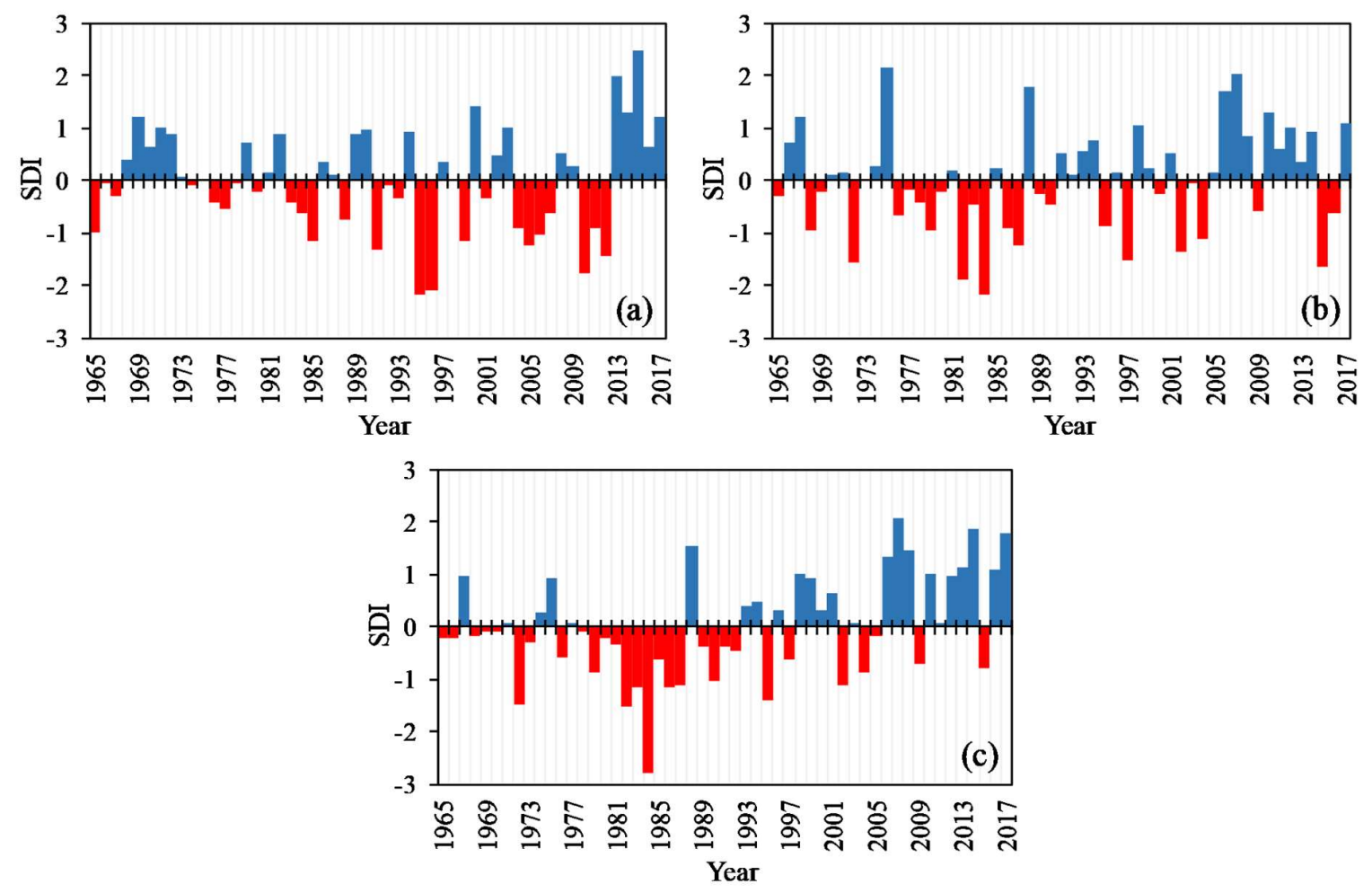

Fig. 3 Temporal analysis of river flow at Khartoum gaging station: a) April, b) September, and c) annual 

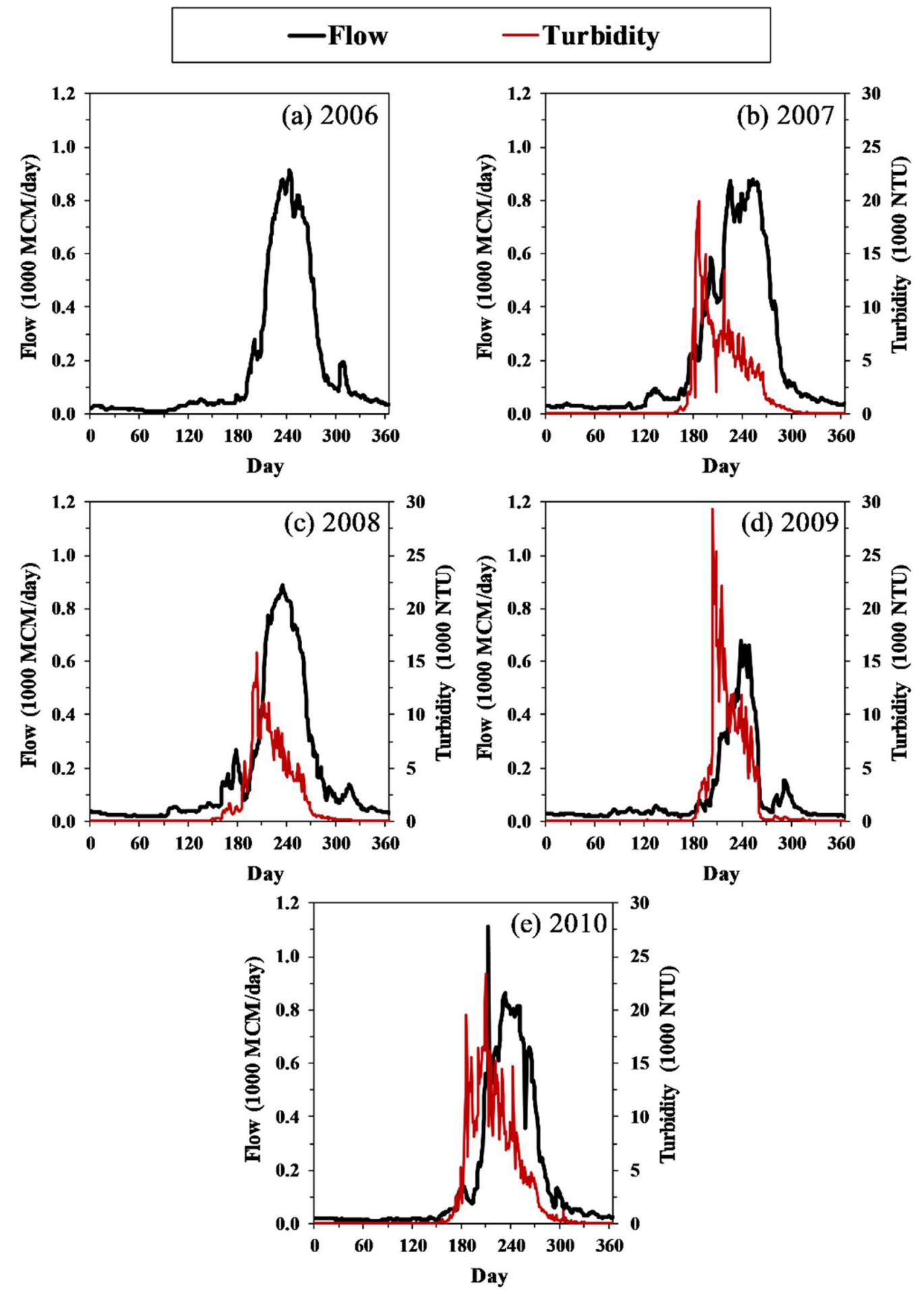

Fig. 4 Annual cycle of turbidity and river flow for Bahri water supply plant for 2006 to 2010 (2006: flood year; 2009: drought year) 

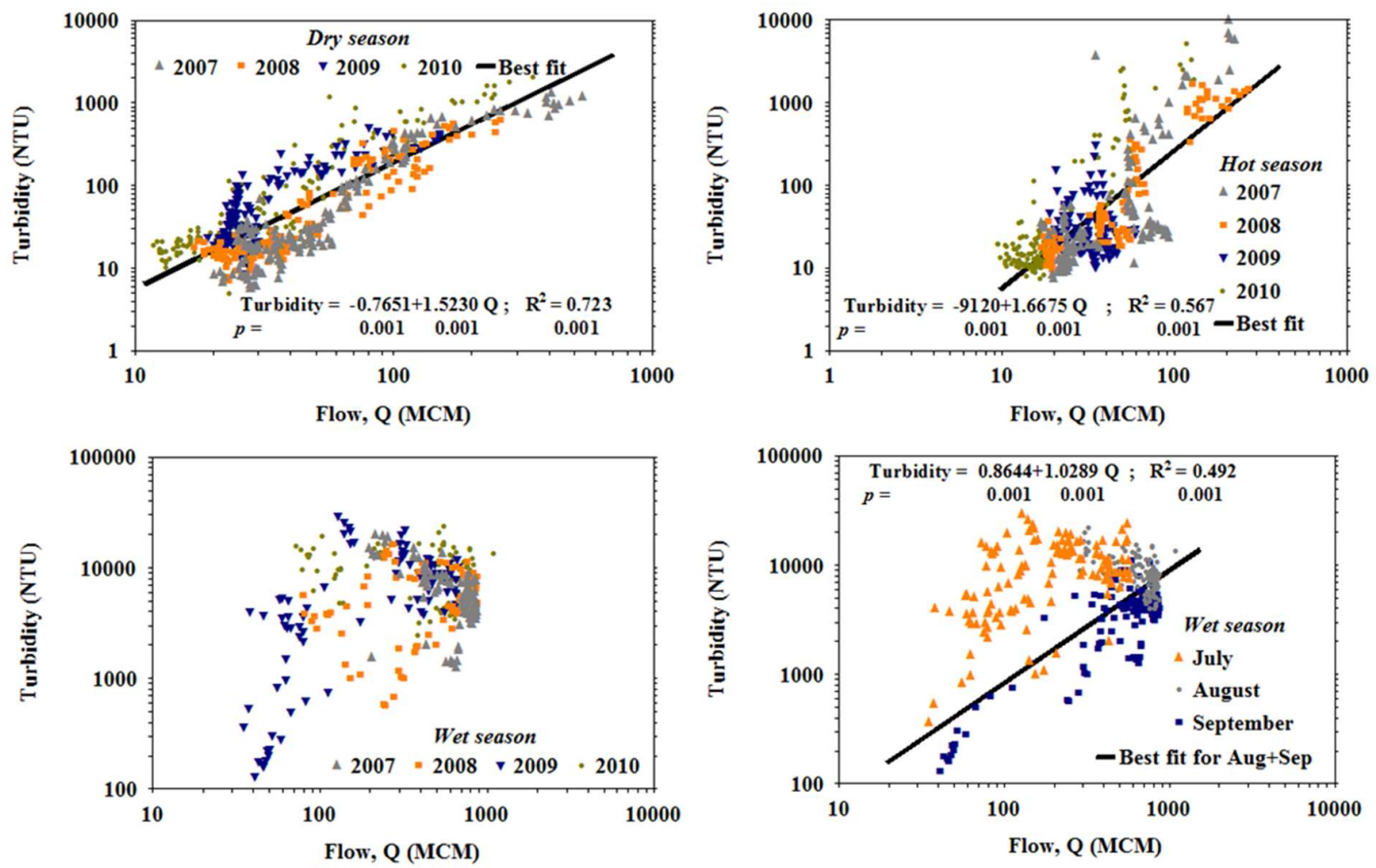

Fig. 5 Turbidity versus flow (Q) for the three seasons for Bahrai Water Treatment Plant. Dry season: Oct to Feb; hot season: Mar to Jun; wet season: Jul to Sep 
a)

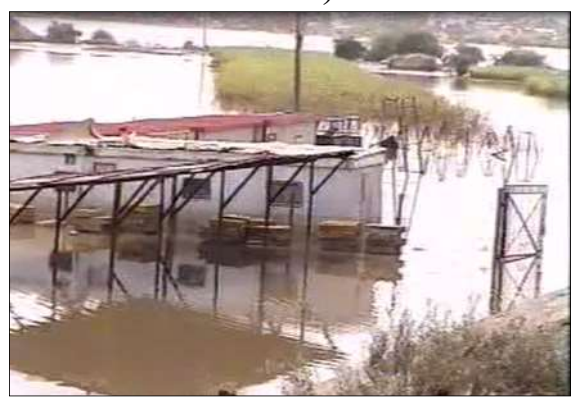

c)

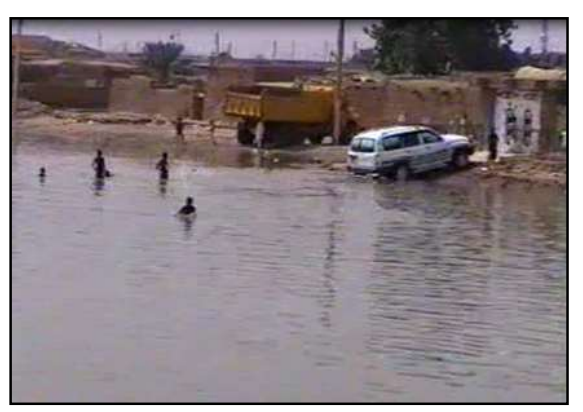

b)

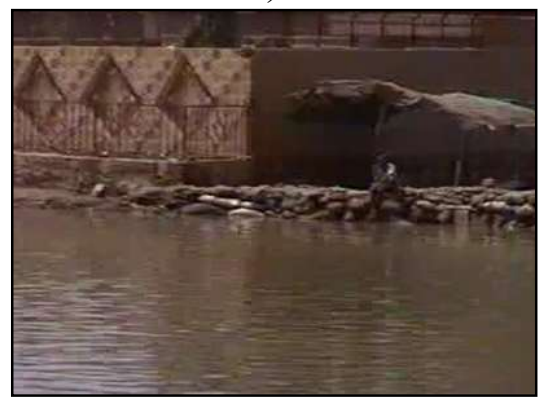

d)

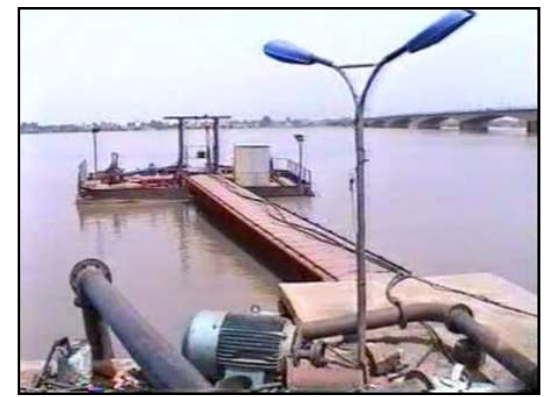

Fig. 6 Flood severity in Khartoum State during September 2006: a) A view from Shambat Bridge, Bahri (Khartoum North, of inundated agricultural lands on the banks of the Main Nile. b) and c) Nile floodwater reaching housing areas at Elfitaihab, Omdurman, and d) Old intake at Bait Elmal Water Treatment Plant within the river course (flooded area) (Photos: Elagib, 5 September 2006) 
a)

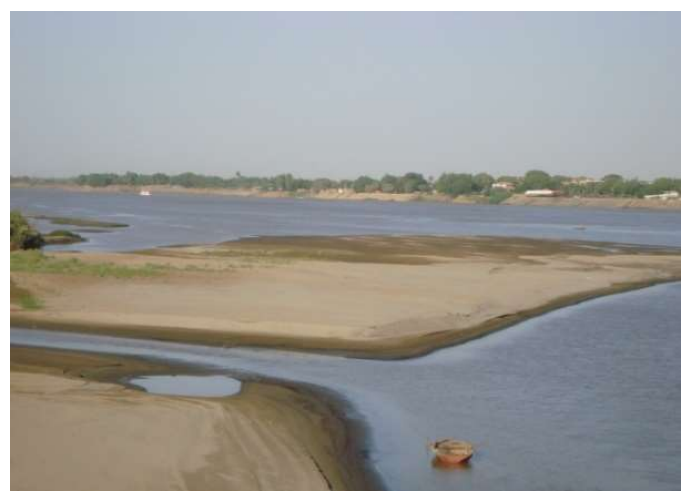

c)

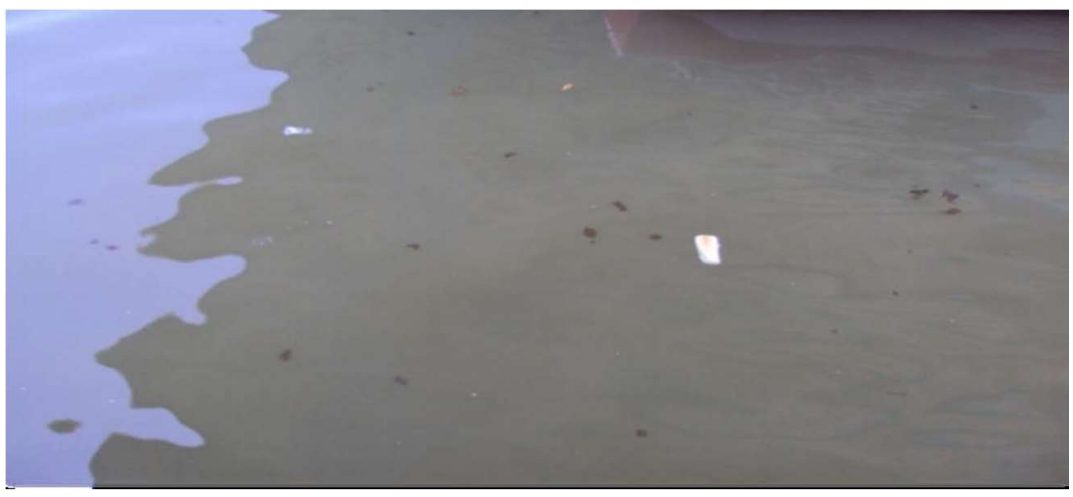

d)

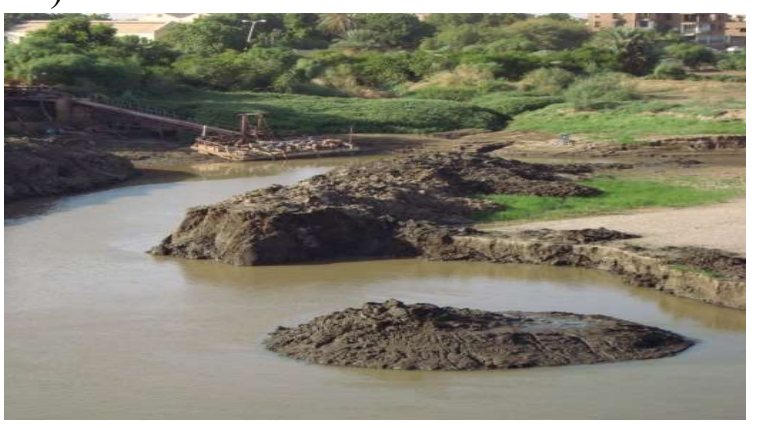

b)

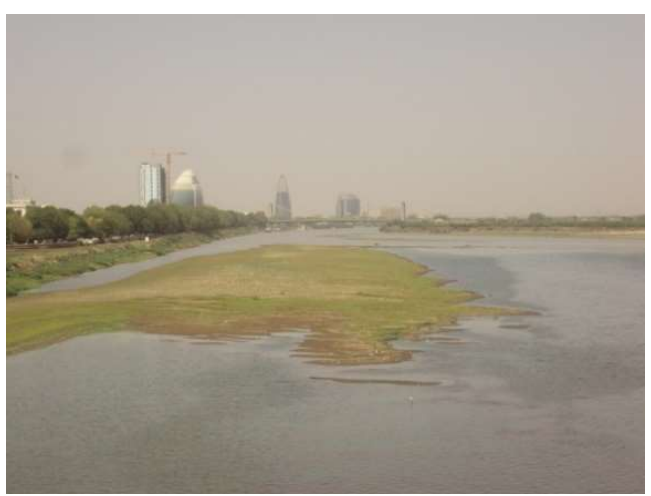

e)

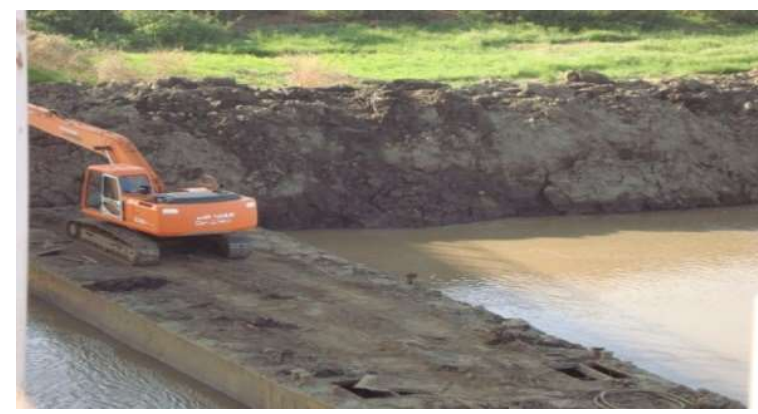

Fig. 7 Drought severity in Khartoum State during April 2010: a) and b) Islands formation in the Nile near Mek Nimer Bridge on the Blue Nile close to Bahri Water Treatment Plant (WTP), c) Algal blooms in Blue Nile, and d) and e) Construction of a new intake for Bait Elmal WTP (see Fig. 1) due to decreased river water level (compare with Fig. 6d). (Source of photos: A. Abdallah). 
a)

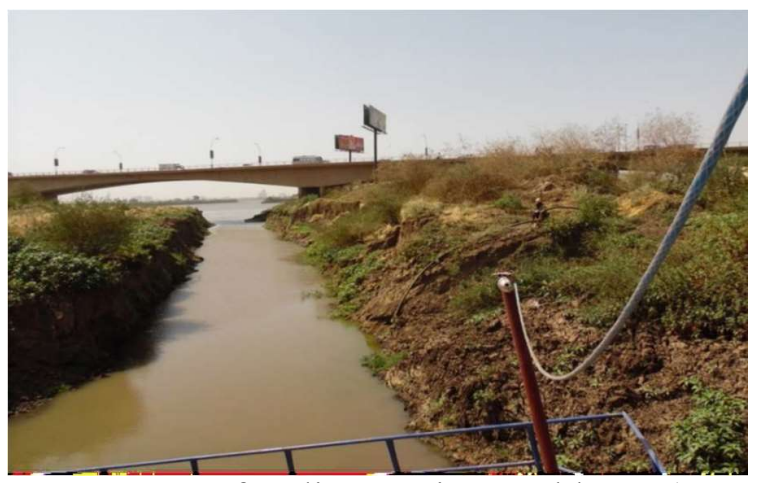

b)

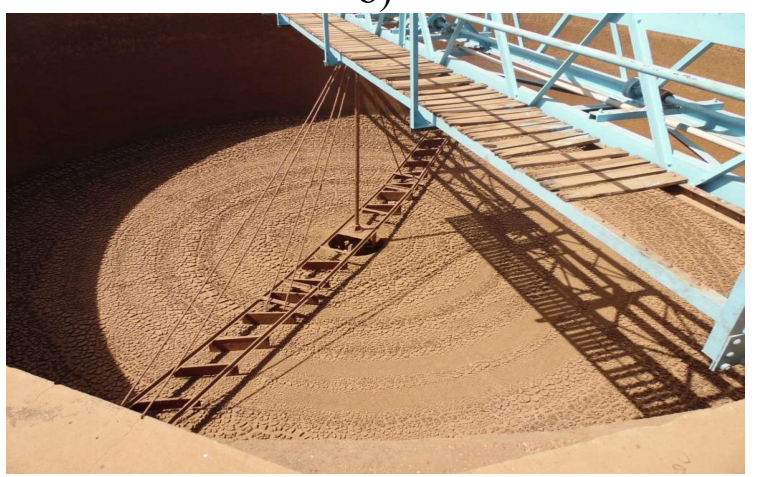

Fig. 8 Impacts of sedimentation problem: a) Narrowed river width near Shambat Bridge on the Main Nile due to accumulation of sediment and b) High turbidity level during the water treatment process at Bait Elmal Water Treatment Plant (Photo: Gore, March 2015).
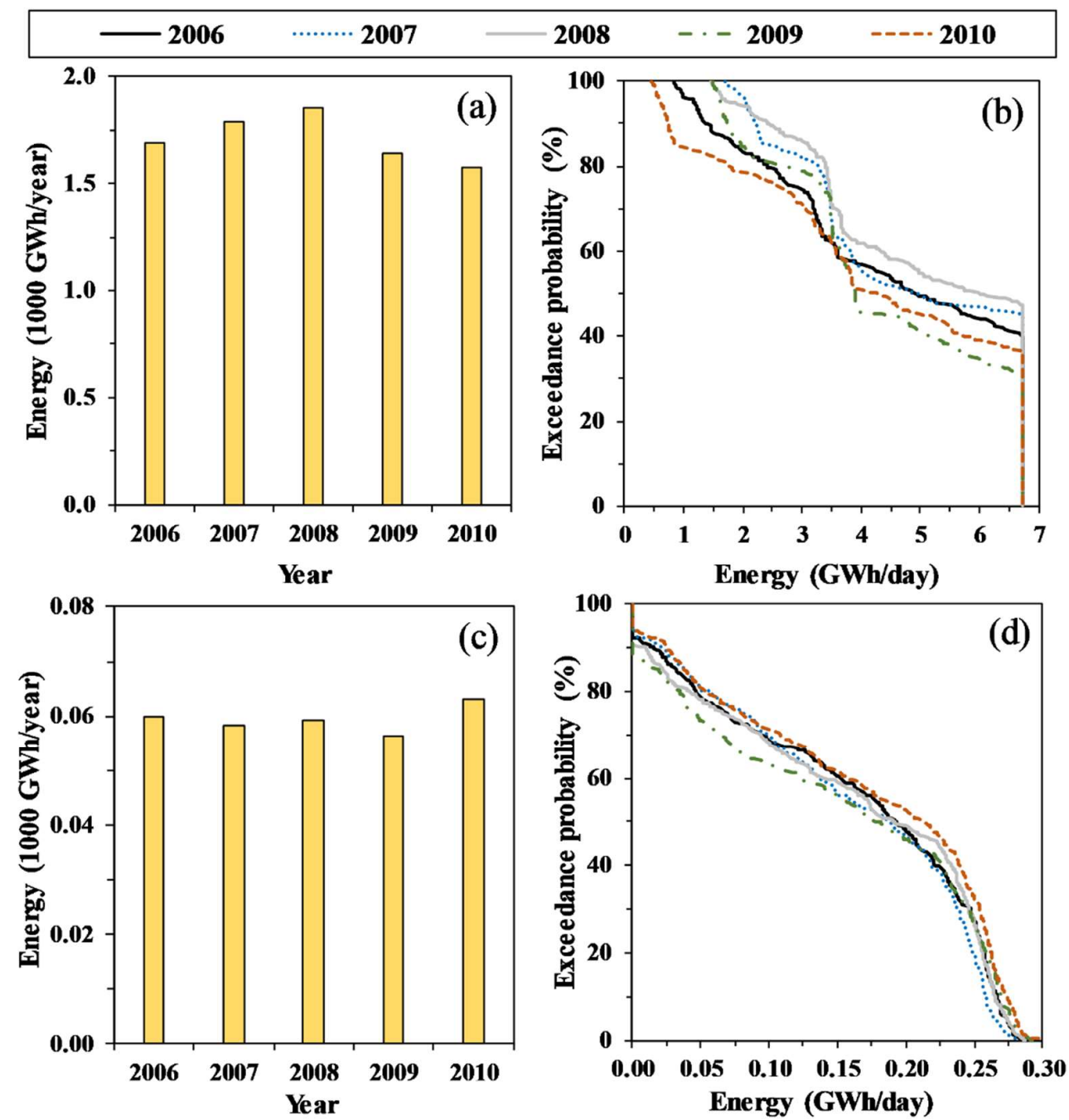

Fig. 9 Hydropower generation and corresponding probability of exceedance during 2006-2010: a) and b) Roseires Dam and c) and d) Jebel Aulia Dam 
Table 1 Nature of questions used in the interviews

\begin{tabular}{|c|c|}
\hline Question & Answer \\
\hline $\begin{array}{l}\text { I. When did you start observing climate variations-induced changes } \\
\text { leading to the loss of crop productivity }\end{array}$ & $\begin{array}{l}\text { a. last } 5 \text { years } \\
\text { b. last } 10 \text { years } \\
\text { c. the start of my working years } \\
\text { d. since childhood } \\
\text { e. never }\end{array}$ \\
\hline $\begin{array}{l}\text { II. Perception of decline of crop productivity } \\
\text { 1) What are the types of crops you are cultivating? }\end{array}$ & \\
\hline 2) If you observe decline of crop productivity, what are the reasons? & $\begin{array}{l}\text { a. Increasing aridity } \\
\text { b. Poor soil fertility } \\
\text { c. Weed invasion } \\
\text { d. Inferior seeds } \\
\text { e. Insect and pest invasion } \\
\text { f. Others (specify) }\end{array}$ \\
\hline III. Adaptations options & \\
\hline $\begin{array}{l}\text { 1) What are the agricultural adaptation strategies (measures) you have } \\
\text { taken to cope with climate change and aridity }\end{array}$ & $\begin{array}{l}\text { a. Early cultivation } \\
\text { b. Delayed cultivation } \\
\text { c. Cultivation of early maturing varieties } \\
\text { d. Crop rotation } \\
\text { f. More weeding times } \\
\text { g. Soil conservation } \\
\text { h. Intercropping } \\
\text { i. Practice supplementary } \\
\text { irrigation/modern irrigation } \\
\text { j. Fertilizers and pesticides } \\
\text { k. Mulching } \\
\text { 1. Others (specify) }\end{array}$ \\
\hline $\begin{array}{l}\text { 2) What are the main barriers/challenges facing you as a farmer to } \\
\text { adapt to changing climate? }\end{array}$ & $\begin{array}{l}\text { a. Lack of machinery } \\
\text { b. Lack of finance/credit } \\
\text { c. Lack of improved seeds } \\
\text { d. Shortage of labour } \\
\text { e. Insects and pests } \\
\text { f. Lack of meteorological information } \\
\text { g. Others (specify): }\end{array}$ \\
\hline
\end{tabular}


Table 2 Characteristics of yearly flow and turbidity for selected years. $\mathrm{Cv}$ is the intra-annual coefficient of variation

\begin{tabular}{|c|c|c|c|c|c|c|}
\hline Year & & 2006 & 2007 & 2008 & 2009 & 2010 \\
\hline \multicolumn{7}{|l|}{ Flow data } \\
\hline & Annual (MCM) & 253.9 & 277.0 & 257.2 & 188.6 & 243.6 \\
\hline & Peak (MCM) & 912.4 & 878.9 & 887.2 & 679.5 & 1109.9 \\
\hline & Date of peak & 01-Sep-06 & 10-Sep-07 & 22-Aug-08 & 26-Aug-09 & 10 -Sep-10 \\
\hline & Annual Cv (\%) & 148.1 & 130.3 & 137.9 & 154.3 & 155.6 \\
\hline & Wet season $\mathrm{Cv}(\%)$ & 53.8 & 32.7 & 51.3 & 75.7 & 50.8 \\
\hline \multicolumn{7}{|l|}{ Turbidity data } \\
\hline & Peak (NTU) & & 19870 & 15856 & 29351 & 23388 \\
\hline & Date of peak & & 6-Jul-07 & 22-Jul-08 & 23-Jul-09 & 29-Jul-10 \\
\hline & Annual Cv (\%) & & 187.8 & 189.5 & 232.7 & 181.0 \\
\hline & Wet season $\mathrm{Cv}(\%)$ & & 59.8 & 58.5 & 84.1 & 48.4 \\
\hline Time lag between peaks & & & 66 & 31 & 34 & 12 \\
\hline
\end{tabular}

